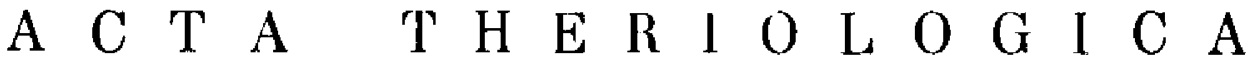 \\ VOL. XV, 29: $465-515$. \\ BIAEOWIEŻA \\ 15.XI1.1970
}

\author{
Whadysław A U L A K
}

\section{Small Mammal Communities of the llialowicza National Park}

[With 18 Tables \& 23 Figs]

\begin{abstract}
Trapping of small epigeic mammals was carried out from 1946-1955 in 10 biotopes in the Bialowieza National Park, using pitfalls. The biotope preferences and domination of species in communities occupying the various biotopes were determined for the 14 species found belonging to the orders Insectivora and Rodentia. The relative density of Micrommalia was compared between the different biotopes. Comparison was made of the similarity of the Micromammalia communities in the biotopes and it was found that the order of biotopes arranged in ecological sequence according to similarities of phytocenoses and zoocanoses is similar. Variations were found to oecur in the structure of communities in successive years of observations, which demonstrated that long-term trapping is essential for definition of the structures of zoocenoses. Fluctuations were found to differ in character from the long-term aspect in Insectivora and Rodentia. Abiotic factors (chiefly the winter period) were found to affect variations in numbers and the structure of Micromammalia communities.
\end{abstract}

1. Introduction

466

2. Material and methods . . . . . . . . . . . . . . . 467

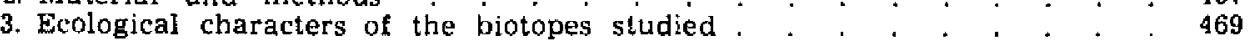

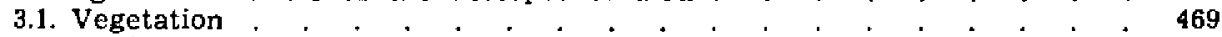

3.2. Habitat factors . . . . . . . . 474

4. Occurrence of Micromammalia in different biotopes $\quad 477$

4.1. Biotope preferences . . . . . . . . . . . . . , , 477

4.2. Dominant species . . . . . . . . . . . . . 480

4.3. Relative density of Rodentia and Irsectivora . . . . . . . . . . 485

5. Micromammalia communities

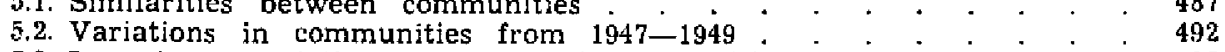

5.3. Long-term variations in mammal communities . . . . . . . 496

5.4. Variations in captures of Micromammalia and the character of fluctuations found in Insectivora and Rodentia... . . . . . . . 499

5.5. Effect of abiotic and biotic factors on qualitative variations in communities

6. Discussion

7. References

8. Streszczenie

\section{INTRODUCTION}

Studies on Micromammalia communities are rot so far advanced as autecological studies. Papers so far published on communities of small mammals in forest 
(Kowalski, 1950; Pivovarova, 1955; Stieve, 1955; Zejda \& K lima, 1958; Grodzinski, 1959; Haitlinger \& Korzeniowski, 1962; Kratochvil \& Gaisler, 1967) and in town biotopes (Chudoba, Huminski \& Wojcik, 1961), in successively altered areas (Chudoba \& $\mathrm{Huminski}, 1961$ ), and even in human communities ( $\mathrm{Chu} \mathrm{doba} \& \mathrm{Humins} \mathrm{h} \mathrm{i}$, 1963) deal with investigations made in different areas, in different habitats, by different methods and in different periods of time. Although all these and other studies contribute many new data to the species composition and structure of such animal communities, they are not comparable. In adcition, studies on communities in forest biotopes were made mainly in managed, and consequently unnatural tree stands, or in young tree plantations, where field species such as $A$. agrarius and $M$. arvalis, were present. These species may compete to some extent with forest species (Andrzejewski \& Wroclawek, 1961; Haitlinger \& Korzeniowski, 1962), and may significantly alter the composition of the Micromammalia community. Analysis of such communities yield results which characterize the ecotone rather than the forest biotope.

The casual investigations made so far in forests of the temperate zone therefore do not allow a detailed analysis of Micromammalia communities in forest biotopes to be made. Nor is it possible to compare the communities of different biotopes, nor to examine geographical variation in the communities of similar biotopes, nor to define the role of different species in the communities in different biotopes. In order to exclude factors contributing to contamination of communities by species alien to a given biotope, investigation must be carried out in large stretches of natural or nearly natural forest, by a standard method, and over a long period of time to eliminate seasonal and yearly variation.

The purpose of the present study, is to analyse communities of ground-dwelling Micromammalia in varied natural biotopes within the extensive Białowieża Primeval Forest.

A group of populations of small Insectiora and Rodentia, whose quantitative composition and dominance relations are determined by habitat factors and inter- and intra-species relations, were considered as a community of ground-dwelling Micromammalia. Communities were considered different when they differed from each other in quantitative and qualitative relations and in dominance structure, which in turn reflects the action of ecological factors on the group of Micromammalia.

Particular attention was paid to the problems of biotope preference exhibited by different Micromammalia and also to variations in the preference index over a period of several years. Dominance of different species of small mammals in the communities and variations in such dominance over a long period were also studied. The relative densities of Micromammalia in different biotopes were assessed, as also were variations in communities over a long period. Examination was also made of the effect of some habitat factors on qualitative variations in the communities. 


\section{MATERIAL AND METHODS}

Trapping areas for Micromammalia were used year after year (from 1946 to 1955) in the Bialowieza National Park $(B N P$ ), in 10 differentiated biotopes ( $\mathrm{K}$ a $\mathbf{r}$ p i i $s \mathbf{k}$, 1949), as part of the research programme of the Forest Research Institute (FRI). Fach area was $0.25 \mathrm{ha}$ in extent $(50 \times 50 \mathrm{~m})$. Fifty pitfall traps $10-12 \mathrm{~cm}$ in diameter and $30 \mathrm{~cm}$ deep, were placed on each of these areas. They were arranged in a grid $5 \times 10 \mathrm{~m}$, and sunk flush with the soil surface. In periodically flooded areas the pitfalls were located at the cross-over points of a wooden latticework. In an aquatic biotope the pitfalls were placed on a floating frame of struts. In the other biotopes the traps were connected by paths along which the herb layer was worn down to the mineral soil. (The biotopes distinguished include 8 types of forest associations and two types of plant associations found in the interior of forests Table 1). Traps were inspected and material collected every two days throughout

Table $1_{+}$

Comparison of nomenclature of study habitats after Karpińs ki (1949) and after the $B r$ a $u n-B l a n q u e t$ school.

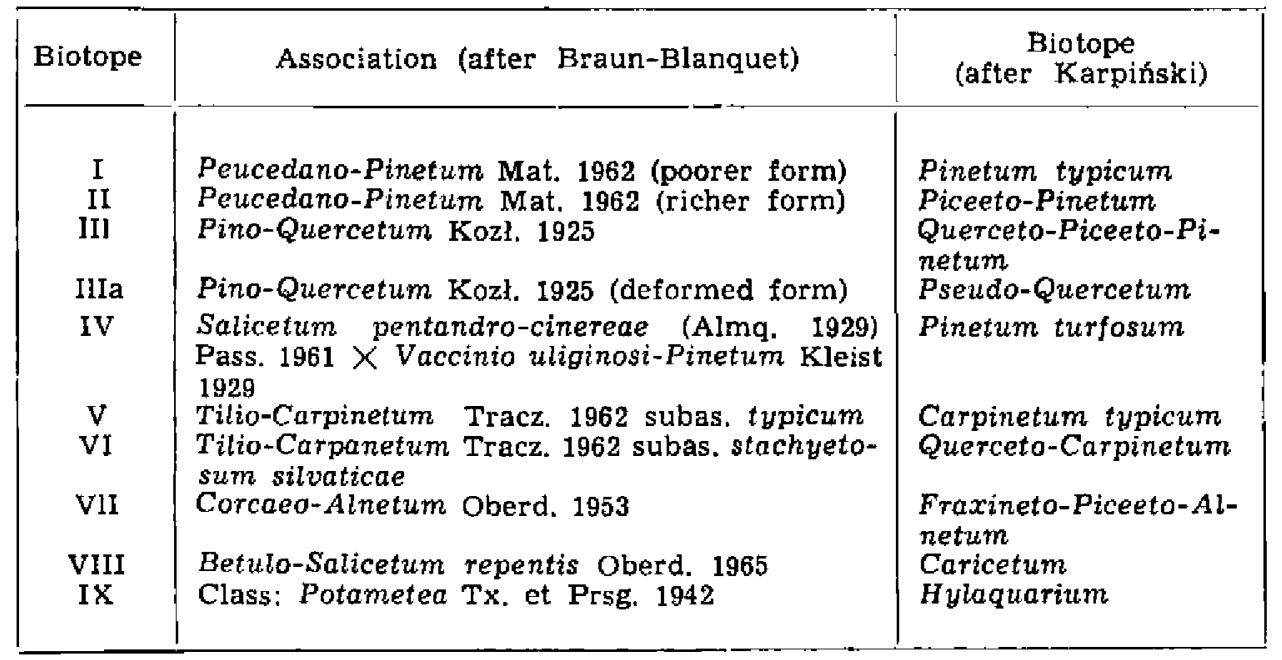

the whole trapping period. Details of trapping technique and laboratory processing of animals collected and the locations of the trapping areas, are to be found in the study by Borowski \& Dehnel (1952). The specimens collected are currently kept in the Mammals Research Institute, Polish Academy of Sciences at Bialowieza.

The traps placed on the study areas caught small ground-living mammals - Insectivora and Rodentia - and only they form the subject of this paper. A total of 14,429 small mammals belonging to 14 species were caught (Table 2). In addition to these, 42 moles Talpa europaea $\mathrm{L}$ in $\mathrm{n}$ a $\mathrm{us}, 1758$ and 11 dormice Dryomys nitedula (Pallas, 1779) were caught. Neither of these two species was included in the discussion, since (1) the trapping method used was not appropriate for them and (2) they do not belong to the epigeic fauna.

It may be assumed that the 14 species of small mammals found constitute the complete range of species for those biotopes of the Bialowieza Primeval Forest 
which are situated at a distance from cultivated land and are not affected by human activities.

Analysis of differences in Micromammalia between biotopes could be made only on the basis of material for the period 1947-1949, when the trapping areas were functioning in all biotopes (Fig, 1). COnly the period 1948-1949 was analysed for areas $V I I I$ and $I X$. In cases in which quantitative indices were calculated for the period 1947-1949 for all biotopes, the quantitative data from area VIII and $I X$ refered to the comparable period for the other areas - 1948-1949).

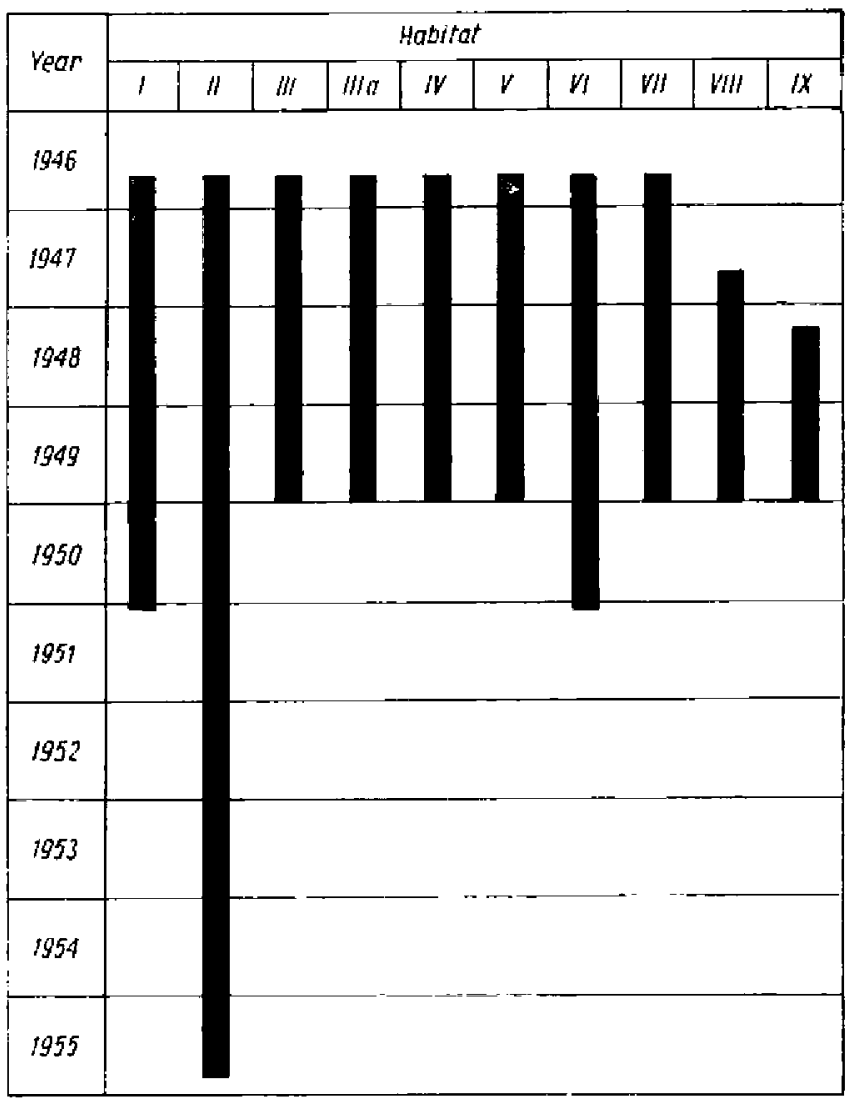

Fig, 1, Working periods of trapping areas.

Long-term fluctuations in Micromammalia are examined mainly on area $I$, in which trapping was carried out for the period 1948-1955.

Despite the abundance of material, detailed analysis often had to be based on the numerically dominant species only, since less numerous species formed too small a percentage of the numbers caught. The trapping method used gives only relative and not absolute numerical data. It was assumed that captures are in proportion to the activity of Micromammalia and this depends to a great degree on 
population density. Although the restlts obtained do not give true indices of absolute density, it was possible, on the basis of material collected, to compare Micromammalia communities between biotopes and their variations in time.

\section{ECOLOGICAL CHARACTERS OF THE BIOTOPES STUDIED}

The biotopes of the Bialowieża National Park used in this study have been dealt with in many scientific papers, which contain detailed ana-

Table 2.

Numbers of Micromammalia caught.

\begin{tabular}{|c|c|}
\hline Species & Numbers \\
\hline $\begin{array}{l}\text { 1. Sorex araneus Linnaeus, } 1758 \\
\text { 2. Sorex caecutiens Laxman, } 1786 \\
\text { 3. Sorex minutus L in a d } 1766 \\
\text { 4. Neomys fodiens (P n a t, } 1771 \text { ) } \\
\text { 5. Neomys anomalus Cabrera, } 1907\end{array}$ & $\begin{array}{r}6485 \\
150 \\
2184 \\
628 \\
152\end{array}$ \\
\hline Insectivora & y E99 \\
\hline 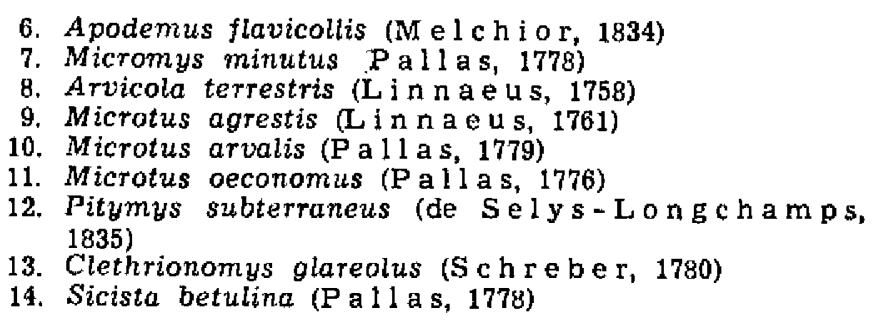 & $\begin{array}{r}319 \\
375 \\
62 \\
452 \\
83 \\
198 \\
661 \\
2244 \\
436\end{array}$ \\
\hline Rodentia & 4850 \\
\hline Micromammalia & 14429 \\
\hline
\end{tabular}

lyses of habitat factors. The following description includes those published results which could be of significance to the epigeic communities of Micromammalia.

\subsection{Vegetation}

When setting up long-term trapping areas in the $B N P, \mathrm{~K}$ a r pin s $\mathrm{ki}$ chose the most typical stretches of the biotopes he distinguished. At that time there were no detailed phytosociological descriptions of the BNP associations. These were not made until later, by $\mathrm{Matuszkiewicz}$ (1952). Biotopes distinguished by $\mathrm{K}$ a r p in $\mathrm{sk}$ i (1949) include almost all 
the main plant associations of the BNP, except for Carici elongatae-Alnetum $\mathrm{K}$ o c h, 1926, which occupies a fairly considerable area. This association and also Circaeo-Alnetum O b e d, 1953, were treated jointly by $\mathrm{K}$ a r pińs ki and termed Fraxineto-Piceeto-Alnetum. Detailed ecological examination was made chiefly of 7 types of forest associations

Table 3.

Plant dominants in herb layer (*C* level), *)

\begin{tabular}{|c|c|}
\hline Biotope & Species \\
\hline I & $\begin{array}{l}\text { Vaccinium myrtilius, Calamagrostis arundinacea, Trientalis europaea, } \\
\text { Convallaria maialis }\end{array}$ \\
\hline II & $\begin{array}{l}\text { Vaccinium myrtillus, Vaccinium vitis-idaea, Calamagrostis arundiana- } \\
\text { cea, Molinia coerulea, Oxalis acetosella, Majanthemum bifolium, Lu- } \\
\text { zula pilosa }\end{array}$ \\
\hline Il1 & $\begin{array}{l}\text { Oxalis acetosella, Calamagrostis arundinacea, Vaccinium murtillus, } \\
\text { Majanthemum bifolitum, Carex digitata, Millium effusum, Pirola se- } \\
\text { curda, Goodyera repens }\end{array}$ \\
\hline IIIa & $\begin{array}{l}\text { Oxalis acetosella, Stellaria holostea, Veronica officinalia, Millium effu- } \\
\text { sum, Calamagrostis arundinacea, Carex montana, Galium Schultesii }\end{array}$ \\
\hline IV & $\begin{array}{l}\text { Dryopteris thelypteris, Phragmites communis, Vaccinium myrtillus, } \\
\text { Lysimachia vulgaris, Pirola secunda, Calamagrostis canescens, Lysi- } \\
\text { machia thyrsiflora, Lycopus europaeus, Oxycoccus quadripetalus, Equi- } \\
\text { setum palustre }\end{array}$ \\
\hline $\mathrm{V}$ & $\begin{array}{l}\text { Anemone nemorosa, Galeobdolon luteum, Oxalis acetosella, Dentaria } \\
\text { bulbifera, Adoxa moschatelina, Asperula odorata, Viola Riviniana, Vio- } \\
\text { la silvestris, Aegopodium podagraria, Stellaria holostea, Majanthe- } \\
\text { mum bifolium }\end{array}$ \\
\hline VI & $\begin{array}{l}\text { Anemone nemorosa, Ficaria verna, Dentaria bulbifera, Corydatis soli- } \\
\text { da, Aegopodium podagraria, Urtica dioica, Athyrium filix-femina, Ga- } \\
\text { leobdolon luteum }\end{array}$ \\
\hline VII & $\begin{array}{l}\text { Urtica dioica, Impatiens noli-tangere, Mercurialis perennis, Chruso- } \\
\text { splenium alternifolium, Oxalts acetosella, Galeobdolon luteum, Poa } \\
\text { trivialis, Circaea alpina }\end{array}$ \\
\hline VIII & $\begin{array}{l}\text { Menyanthes trifoliata, Calamagrostis neglecta, Festuca rubra, Oxycoc- } \\
\text { cus quadripetalus, Carex dioica, Agrostis canina, Carex lasiocarpa, } \\
\text { Carex diandra, Carex rostrata, Epilobium palustre }\end{array}$ \\
\hline
\end{tabular}

*) Names of species after: Szafer, Paw lowski \& Kulczy ński (1953).

(I-VII), one contaminated association (IIIa) and two associations in the interior of the forest (VIII and IX). One of the forest associations is a complex association (IV). In addition, in the coniferous forest associations, according to current systematics two of $\mathrm{K}$ a r pins $\mathrm{k}$ i's associations, i.e. Pinetum typicum (I) and Piceeto-Pinetum (II) belong to the 
association Peucedano-Pinetum Mat., 1962 (Table 1). In order to equate the terms used by $\mathrm{Karpinski}$ to the phytosociological terminology of the Braun-Blanquet school, use was made of the phytosociological lists made by the Forest Research Institute (Dr. A. S o k o low$\mathrm{ski}$ and Dr. J. Wolak). These lists were made in 1959-1966 later than the captures of small mammals, but in the natural associations of

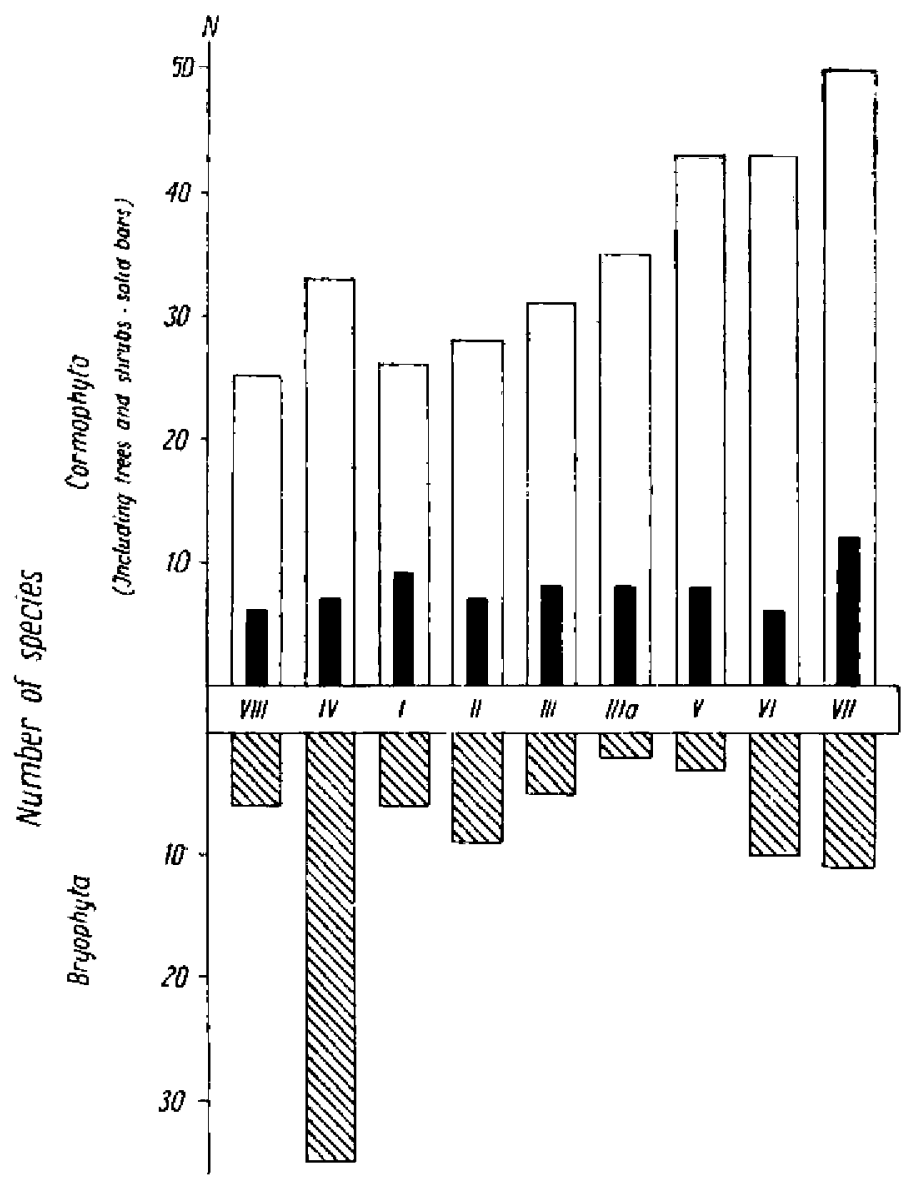

Fig. 2. Number of herb layer species in terrestrial biotopes.

the $B N P$ the interval between these two periods is too short for appreciable succession to have occurred. The only significant change was exhibited by Caricetum (VIII), into which birch has begun to encroach fairly markedly during recent years. Until the time the phytosociological descriptions were made this biotope had, however, remained a non-forest association, with predominance of those elements in the herb layer 
which existed there during the period before birch encroached upon it. The present study contains only a table of plant dominants in the herb layer (Table 3), without giving complete floristic lists, since it was considered that the most important vegetation in the herb layer is that occurring in great abundance and forming potential food for herbivores. Floristic wealth increases with increase in fertility of the habitat (Fig. 2). The biotopes fall into a sort of ecological sequence with respect to number of herb layer species (particularly when seed plants and pteridophytes are considered). Some deviation is introduced by Pinetum turfosum (IV);

\begin{tabular}{|c|c|c|c|c|c|c|c|c|}
\hline Genus Hobritat & $N$ & 1 & $" 1$ & III & I/la & $v$ & vI & vill \\
\hline \multicolumn{9}{|l|}{ BETULA } \\
\hline \multicolumn{9}{|c|}{$248=2$} \\
\hline \multicolumn{9}{|l|}{ PICEA } \\
\hline \multicolumn{9}{|l|}{ QUERTUS } \\
\hline \multicolumn{9}{|l|}{ CARPINUS } \\
\hline \multicolumn{9}{|l|}{ TILIA } \\
\hline \multicolumn{9}{|l|}{$A C E R$} \\
\hline \multicolumn{9}{|l|}{ ULMUS } \\
\hline \multicolumn{9}{|l|}{ ALNUS } \\
\hline \multicolumn{9}{|l|}{ FRAXINUS } \\
\hline Fover of frees layer, $\%$ & 75 & 70 & 65 & 70 & 90 & 90 & 80 & 75 \\
\hline
\end{tabular}

Fig. 3. Percentage in layer of tree stand of different species of trees according to degree of cover.

as lowever, this is a complex association the larger number of pteridophytes and seed plants is to be expected. Biotopes with more herb layer species create more trophic niches for consumers. Since primary production of the biotope also increases with habitat fertility ( $\mathrm{Tracz}$ k, 1968), one would expect that in Tilio-Carpinetum and Circaeo-Alnetum the communities of small mammals should be richer both in quantity and quality.

The composition of the tree stands also affects the ecological conditions for small mammals. The quantitative and qualitative composition of the 
tree layer exerts an indirect influence (e.g. ecoclimate) and direct infiuence, through litter fall, particularly of seeds. Two types of biotope can be distinguished: those in which species with light seeds dominate $(I V, I, I I, I I I$ and partly $V I I)$, and those in which a large number of species bear heavy seeds (IIIa, V and VI) (Fig. 3). The latter are thus more favourable to "seed-eaters". Confirmation of this is provided by the dry weight of seeds collected in samplers in 7 forest biotopes during the period 1947-1949 (Table 4). Biotopes IIIa, V and VI are most productive both with respect of the total amount of seeds and of the heavy seeds only. Litter fall may also give evidence of increasing fertility and increased food supply for small mammals in the biotopes studied, from

Table 4.

Weight of seed dry mass in $\mathrm{mg}$. Samples taken with $1 \mathrm{~m}^{2}$ samples placed in 8 forest biotopes during period 1947-1949 (after unpublished data of Forestry Research Institute at Białowieża).

\begin{tabular}{|c|c|c|c|c|c|c|c|}
\hline \multirow{2}{*}{ Species bearing: } & \multicolumn{7}{|c|}{ Biotope } \\
\hline & I & II & III & IIIa & $\mathrm{V}$ & VI & VII \\
\hline $\begin{array}{l}\left.\text { Heavy seeds }{ }^{*}\right) \\
\text { Light seeds }\end{array}$ & $\overline{160}$ & $\overline{550}$ & $\begin{array}{r}7.300 \\
200\end{array}$ & $\begin{array}{r}604.730 \\
110\end{array}$ & $\begin{array}{r}170.140 \\
190\end{array}$ & $\begin{array}{r}675.890 \\
1.850\end{array}$ & $\begin{array}{r}13.490 \\
3.030\end{array}$ \\
\hline Total & 160 & 550 & 7.500 & 504.840 & 170.330 & 677.740 & 16.520 \\
\hline
\end{tabular}

*) Quercus, Carpinus, Tilia, Acer, Fraxinus, Coryllus. **) Pinus, Picea, Betula, Alnus, Populus, UImus.

Table 5.

Yearly fall of litter dry mass in $\mathrm{g} / \mathrm{h} \mathrm{m}^{2}$ (after data given by $\mathrm{K}$ a r pin $\mathrm{ski}$, 1954).

\begin{tabular}{|l|c|c|c|c|c|c|c|}
\hline \multicolumn{1}{|c|}{ Biotope } & I & II & III & IV & V & VI & VII \\
\hline $\begin{array}{l}\text { I itter } \\
\text { biomass }\end{array}$ & 14.515 & 19.479 & 23.740 & 17.927 & 33.053 & 32.349 & 45.213 \\
\hline
\end{tabular}

Peucedano-Pinetum to Circaeo-Alnetum (Table 5). The quantity of litter fall gives an indication of the primary production of the tree stand (without wood biomass and seeds).

Using $S$ ör ens e n's formula (M a c f a d y e $n, 1963$ ), floristic similarity coefficients were calculated to compare the qualitative occurrence of seed plants, pteridophytes and bryophytes. On the Czekanowski diagram (Fig. 4) the biotopes are arranged in a kind of ecological sequence from Peucedano-Pinetum to Circaeo-Alnetum. Pseudo-Quercetum (IIIa) is floristically closer to Pino-Quercetum, which would indicate 
that it originated from Pino-Quercetum (III) and not from Tilio-Carpinerum (V) (as suggested by $\mathrm{K}$ a r pins ki, 1949). The wet biotopes (VIII and $I V$ ) do not exhibit any close floristic relationship to the remainder. The biotope Hylaquarium (IX) has been included only to show where it lies in the ecological arrangement.

\subsection{Habitat Factors}

Soil conditions and the ecoclimate are included as habitat factors i.e. physiological properties of the habitat. A soil character of great importance to Micromammalia is its humidity. Also important is the level of the water table, which directly affects soil humidity. In 1949 , both the

\begin{tabular}{|c|c|c|c|c|c|}
\hline & 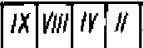 & $f[/ / / H a \mid v$ & 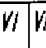 & Type of habitat & Association (Korpiriski, 1949) \\
\hline $1 X$ & & & & Water & Hylaquarium \\
\hline VIIII & & & & \multirow{2}{*}{ Wet habifats } & Caricetum \\
\hline IV & & & & & Pinetum furfosum \\
\hline$\| 1$ & & & & \multirow{4}{*}{$\begin{array}{l}\text { Ory and trophically } \\
\text { poor habitats }\end{array}$} & Piceeto-Pinetum \\
\hline 1 & & & & & Pinetum typicum \\
\hline III & & & & & Querceto-Piceelo-Pinetum \\
\hline$\| / / a$ & & & & & Pseudo-Quercetum \\
\hline $\boldsymbol{V}$ & & & & \multirow{3}{*}{ Fertile habitots } & Carpinetum fypicum \\
\hline Vi & & & & & Quenceto-Corpintiom \\
\hline WIII & & & & & Froxinelo-Piceeto-Alnetum \\
\hline
\end{tabular}

Scole of similority in per cent

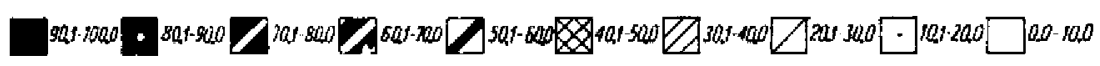

Fig. 4. Diagram of floristic similarity of 10 study biotopes.

average level of the water table and its fluctuations exhibited considerable differences between the biotopes (Fig. 5). Humid biotopes (IV, $V I I$ and $V I I I)$, are recognized by an average Ievel of the water table near ground level (or, in the case of Caricetum (VIII), even above ground level). In these biotopes the amplitude of fluctuations in water level during the year is small. They are thus favourable to hygrophilous species. In the other biotopes the average level of the water table is at least $1 \mathrm{~m}$ below ground level and there are fairly wide fluctuations during the year particularly in the Tilio-Carpinetum biotopes ( $V$ and $V I$ ), where the water level periodically rises fairly high, which may cause excessive humidity in burrows or even flood them. The lowest level of water table is found in Pseudo-Quercetum (IIIa), which accounts for the severe temperature conditions in the soil and the depth to which it freezes.

The pattern of temperature variation in the soil, in which the animals spend $70-80 \%$ of their life, is of importance to the energy balance of 


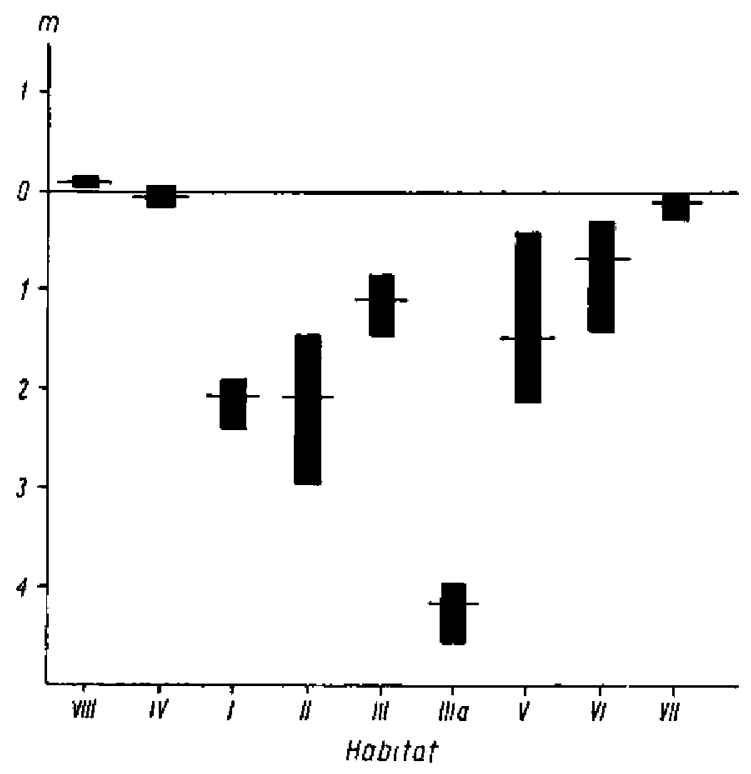

Fig. 5. Average level and yearly amplitude of ground water fluctuations in 1949 (data from O b m i ns $\mathrm{k} \mathrm{i}, 1960$ ).

Fig. 6. Soil temperature at depths of $5-20 \mathrm{~cm}$ in February and July and number of days (N) with soil temperature of $<0^{\circ} \mathrm{C}$ (data from $\mathrm{T}$ o m a n e $\mathrm{k}$, 1953).

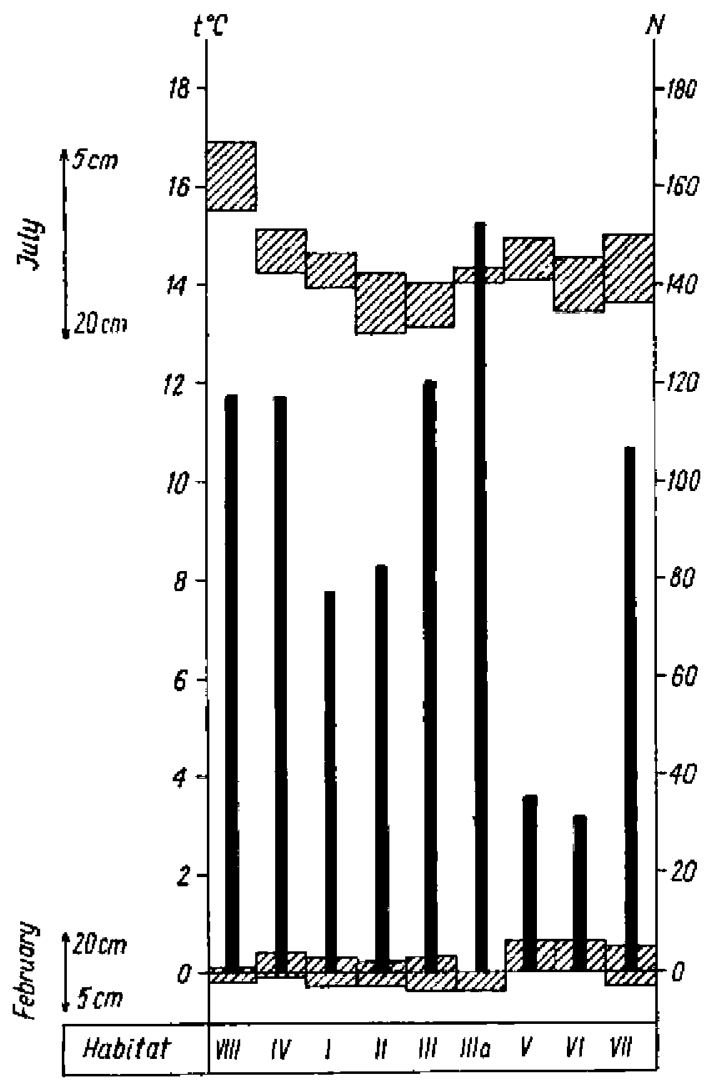


Micromammalia ( $\mathrm{G}$ ó $\mathrm{reck}$, 1968). In winter only small differences are found between biotopes in the average temperatures of the superficial soil layer (Fig. 6). The Tilio-Carpinetum associations ( $V$ and $V I$ ), however, in thich the average soil temperature does not fall below $0^{\circ} \mathrm{C}$ differ markedly from the Pseudo-Quercetum (IIIa), in which the average temperature is always low $0^{\circ} \mathrm{C}$. In summer, far greater differences are found in average temperatures, but these do not exert any important influence on the living conditions of Micromammalia.

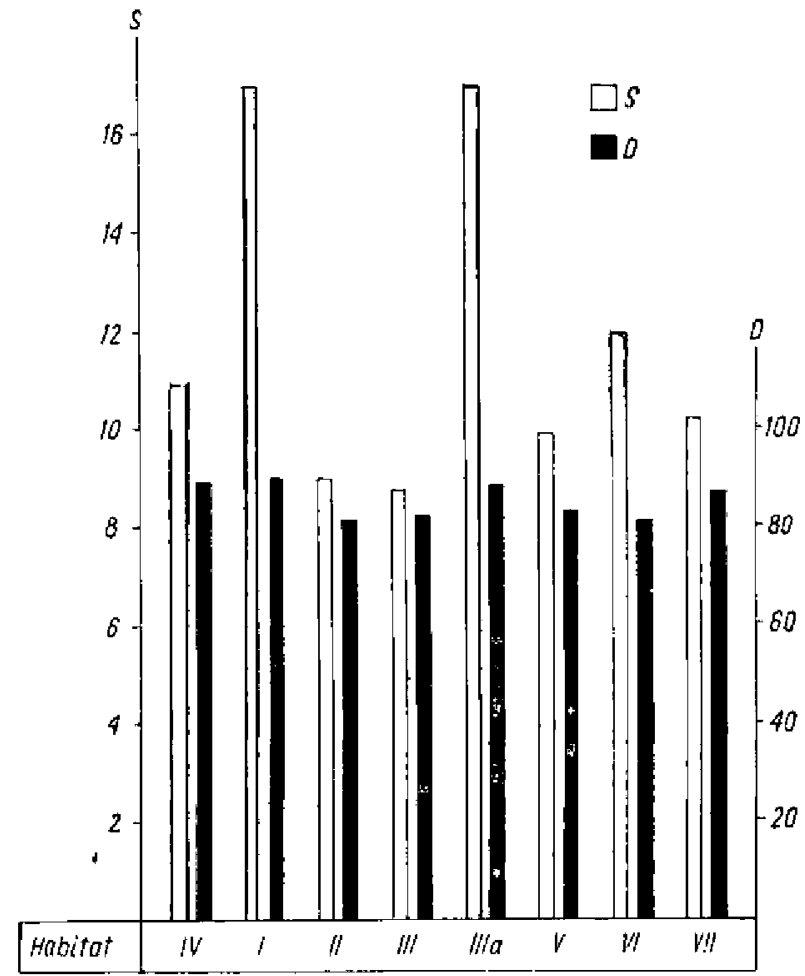

Fig. 7. Average thickness of snow cover $(S)$ in $\mathrm{cm}$ and number of days with snow cover $(D)$ during period January-March 1949 (data from $O \mathrm{~b} m \mathrm{i}$ ń $\mathrm{s} \mathrm{i}, 1960$ ).

Analysis of snow conditions during the winter period, so critical to small mammals (Fig. 7), reveals only slight differences between biotopes in the time for which the snow lies, but considerable differences in the average thickness of cover. Biotopes with a thick snow cover $(V, V I$ and $V I I)$ do not exhibit very low soil temperatures. However, the thick snow cover in Pseudo-Quercetum does not protect the soil from excessive cooling, as the level of ground water is fairly low. 
An important ecological parameter for Micromammalia is the air temperature in the ground level layer. Analysis shows that the most severe temperatures in the air layer are to be found in Pseudo-Quercetum (Fig. 8). Wide fluctuations in average air temperatures in this layer are also found in Caricetum (VII) which is not covered by a tree stand.

The factors discussed above show that the various biotopees provide different living conditions for Micromammalia. Among the forest biotopes undoubtedly the most favourable conditions are provided by Tilio-Carpinetum ( $V$ and $V I$ ), and the least favourable by Pseudo-Quercetum

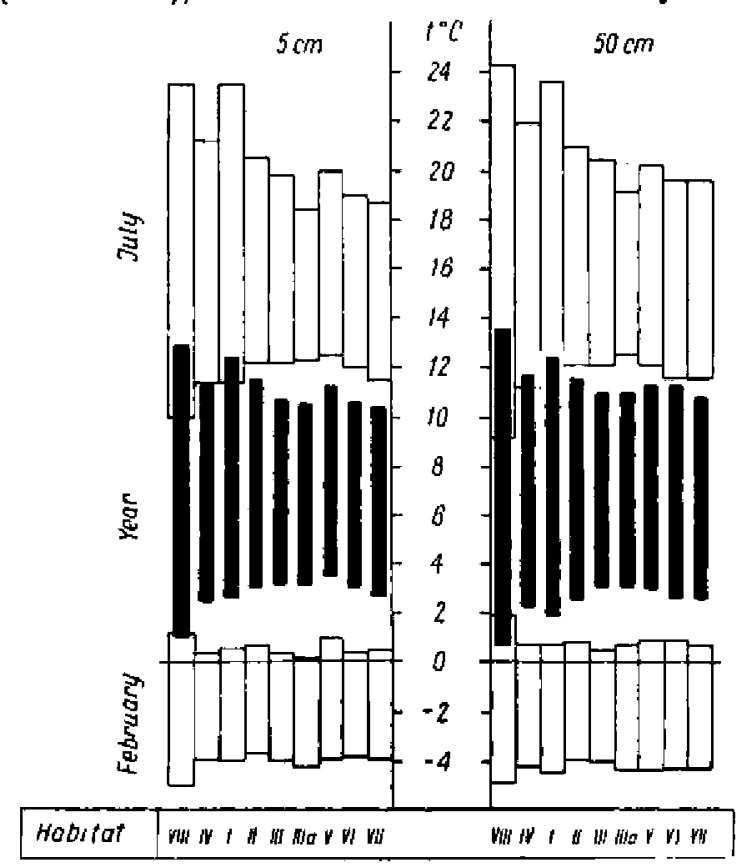

Fig. 8. Intervals of average air temperatures at height of $5 \mathrm{~cm}$ and $50 \mathrm{~cm}$ for February and July and for whole year (data from Tom a nek, 1955).

(IIIa). The humid biotopes (IV, VII, VIII) are the most favourable for hygrophilous species. The action of physical factors in the environment may also be modified by biotic factors.

\section{OCCURRENCE OF MICROMAMMALIA IN DIFFERENT BIOTOPES}

\subsection{Biotope Preferences}

In the present discussion preferences are defined on the basis of the percentage of individuals of the given species caught in a given biotope in relation to the total number of individuals caught during this time in 
all the biotopes. The period 1947-1949 was taken as the analysis period. The following procedure was adopted for including the non-forested biotopes (VIII and IX), in which captures were not made in 1947, in the whole of the material. Specimens captured in 1948-1949 in all biotopes were treated as $100 \%$, and preferences for biotopes $V I I I$ and $I X$ defined in relation to the whole of this material. The percentage obtained for the various species was divided between the forest biotopes in proportion to captures for three years (1947-1949). This procedure is employed in all further discussions of cases in which material from two-year captures in biotopes $V I I I$ and $I X$ are compared with three-year material from the other biotopes.

Material from 1948 in biotope $I X$ is treated as complete even though captures were not begun there until towards the end of April (Fig. 1). This procedure is reasonable since in 1949 very few captures were made in this biotope during the months of January to April.

In addition Hylaquarium differs in its Micromammalia both qualitatively and quantitatively from other biotopes. Consequently the failure to include a few individuals would not distort the picture of the preferences of small mammals in the range of biotopes.

In the diagram illustrating biotope preferences (Fig. 9) a 6-degree scale of preference of a species for a biotope has been used. This made it possible to assess the biotope preferences and the eury- or stenobiotism of each species and to estimate the degree of attractiveness of the different biotopes for species of mammals of for groups of species. Four groups of biotopes can be distinguished on the diagram. The first group consists of one biotope only, Hylaquarium (IX). The species occurring here are closely connected with an aquatic habitat and part of their activity takes place in that habitat. The second group consists of biotopes VIII, VII and $I V$ with high humidity but varied trophic values (see below). The third group consists of Peucedano-Pinetum and Pino-Quercetum (I, II, III and IIIa), fairly dry biotopes with low tropic value, as defined below. The fourth group is formed by Tilio-Carpinetum ( $V$ and $V I$ ), a not very dry biotope, with high trophic value for small mammals, expressed in great floristic wealth, high seed production and both quantitatively and qualitatively rich invertebrate fauna.

It can be seen from Fig. 3 that the biotopes Peucedano-Pinetum and Pino-Quercetum are not the native biotopes of any of the 14 species of mammals. Some species avoid them altogether, while the remainder occur there in small numbers only. Hylaquarium $(I X)$ has its specific composition of micromammalian fauna and is the native biotope of typical hygrophiles ( $N$. fodiens, $N$. anomalus, $M$. minutus, $A$. terrestris and $M$. oeconomus). Biotopes Tilio-Carpinetum ( $V$ and $V I$ ) are native for $A$. flavicollis, 
$M$. arvalis and $P$. subterraneus. $S$. betulina and $M$. agrestis are attached to certain biotopes of the humid group (VIII, VII and IV), depending on their humidity and trophic value.

Analysis of the ecological range occupied by different species reveals a group of eurybiontic species - three species of shrew and C. glareolus (Fig. 9). The remaining species are, to a lesser or greater degree, stenobionts. $S$. minutes more readily occupies humid biotopes than $S$. araneus, which may be due to the more "hygrophilous character " of the species (D e h n e 1, 1949. It would also appear that $N$. fodiens is a more hygrophilous species than $N$. anomalus. Although D e h nel (1950), and B o row$\mathrm{ski} \& \mathrm{Dehnel}$ (1952) hold the opposite opinion, this may be due to the greater activity of $N$. fodiens and the fairly extensive migrations it

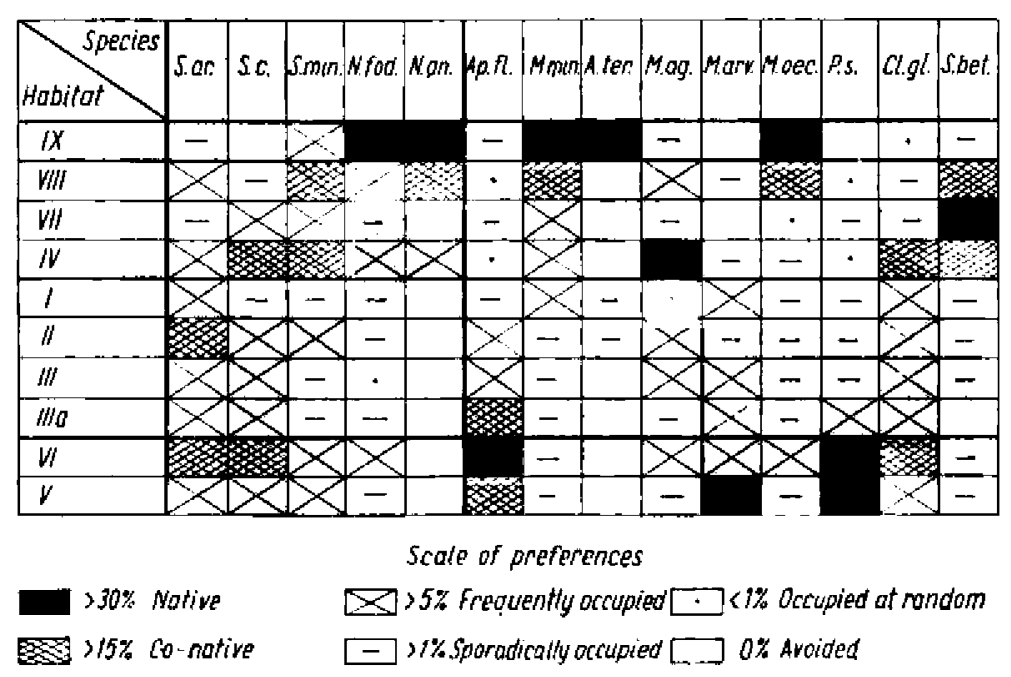

Fig. 9. Biotope preferences of small mammals according to percentage of individuals in each biotope during period 1947-1949.

undertakes, unlike $N$. anomalus. A. flavicollis exhibits distinct preference for biotopes with considerable falls of heavy seeds (cf. also Piv o va r ova, 1955 ; Kormilicina, 1966; A u la k, 1967). M. minutus prefers wet and moist biotopes (Dehnel, 1946); hence the majority of individuals were caught in biotopes $I X$ and VIII. A.terrestris occurs only near bodies of water (IX). The fact that single individuals were encountered in Peucedano-Pinetum biotopes ( $I$ and $I I$ ) may be due to these animals sporadically undertaking fairly long migrations. $M$. agrestis occurs in all biotopes, but its native habitat is the complex association Pinetum turfosum (IV). M. arvalis exhibited the greatest attachment to Tilio-Carpinetum typicum (V), and occurs sporadically in moist 
biotopes (VIII, IV). It is difficult to determine the cause of this species' attachment to chiefly one biotope. It is possible that it is due partly to its migration from fields, since the trapping area in this biotope was situated about $500 \mathrm{~m}$ away from the fields of the Bialowiezia Glade. $M$. oeconomus prefers wet biotopes (VIII and $I X$ ) and occurs only sporadically in the others. $P$. subterraneus never occurs numerously in biotopes other than Tilio-Carpinetum ( $V$ and VI). It prefers fertile biotopes with a rich herb layer ( $P$ i v o v a rova, 1955). It occurs only fortuitously in moist biotopes. $C$. glareolus is an eurybiont and occurs everywhere apart from outstandingly moist biotopes (IX, VIII, VII). The wide ecological range of this species is shown by its occurrence even on ruderal areas ( $\mathrm{H}$ a it $1 \mathrm{ing}$ e $r$, 1965). The fairly considerable numbers of this species in Pinetum turfosum (IV) in 1948 was not a fortuitous phenomenon, since C. glareolus occurs often and numerously on peat bogs and moist areas in other parts of Poland ( $\mathrm{S} \mathrm{k}$ u r a t ow i c z, 1948; H a i t linger \& K or z eniow ski, 1962). S. betulina occupies moist biotopes (VIII, VII, IV) with dense shrub layer and high herb layer (cf. also $\mathrm{K} \mathrm{ubik}, 1952$; Pivovarova, 1955). The avoidance of Pseudo-Quercetum (IIIa) is characteristic of this species and is probably connected with the fact that this is a biotope with extreme temperature range in the air layer immediately above ground level and in the superficial layers of the earth (Fig. 6 and 8). Apart from eurybionts the preference indices for the remaining species clearly define the biotopes optimal for each species of mammal (Fig. 9).

In order to find what influence the study period chosen had on the preference indices obtained and to eliminate any influence of the time factor in such assessments, a comparison was made of the changes in biotope preference index for several species caught in fairly large numbers. It may be seen from table 6 that a change in preference is evident not only in the case of stenobionts (P. subterraneus, $S$. betulina) but also in eurybionts ( $S$. araneus, S. minutus, C. glareolus). The fairly considerable differences in biotope preference indices between the different years indicate that it is incorrect to define the species attachment to a biotope on the basis of a short period of observations (even over a whole year). In the present discussion the author had at his disposal data from three years only, but even so this period is fairly representative, since it covers the year preceding peak numbers, the year of peak numbers and the year of decrease in the numbers.

\subsection{Dominant Specie:}

In order to determine the significance of the different species of Micromammalia in the biotope their degree of dominance was determined, i.e. 
comparison was made of the percentages they form in groups of small mammals, determined separately for Insectivora and Rodentia, since the traps used are to a certain extent selective in their action on these two groups of mammals. Insectivora are caught in larger numbers than ro-

Table 6.

Percentage (preference index) of some species of small mammals in different forest biotopes from 1947-1949. Number of individuals caught in all biotopes taken as $100 \%$. Biotopes arranged in order of most to least densely settled. Preference indices differing visibly in successive years are boldfaced.

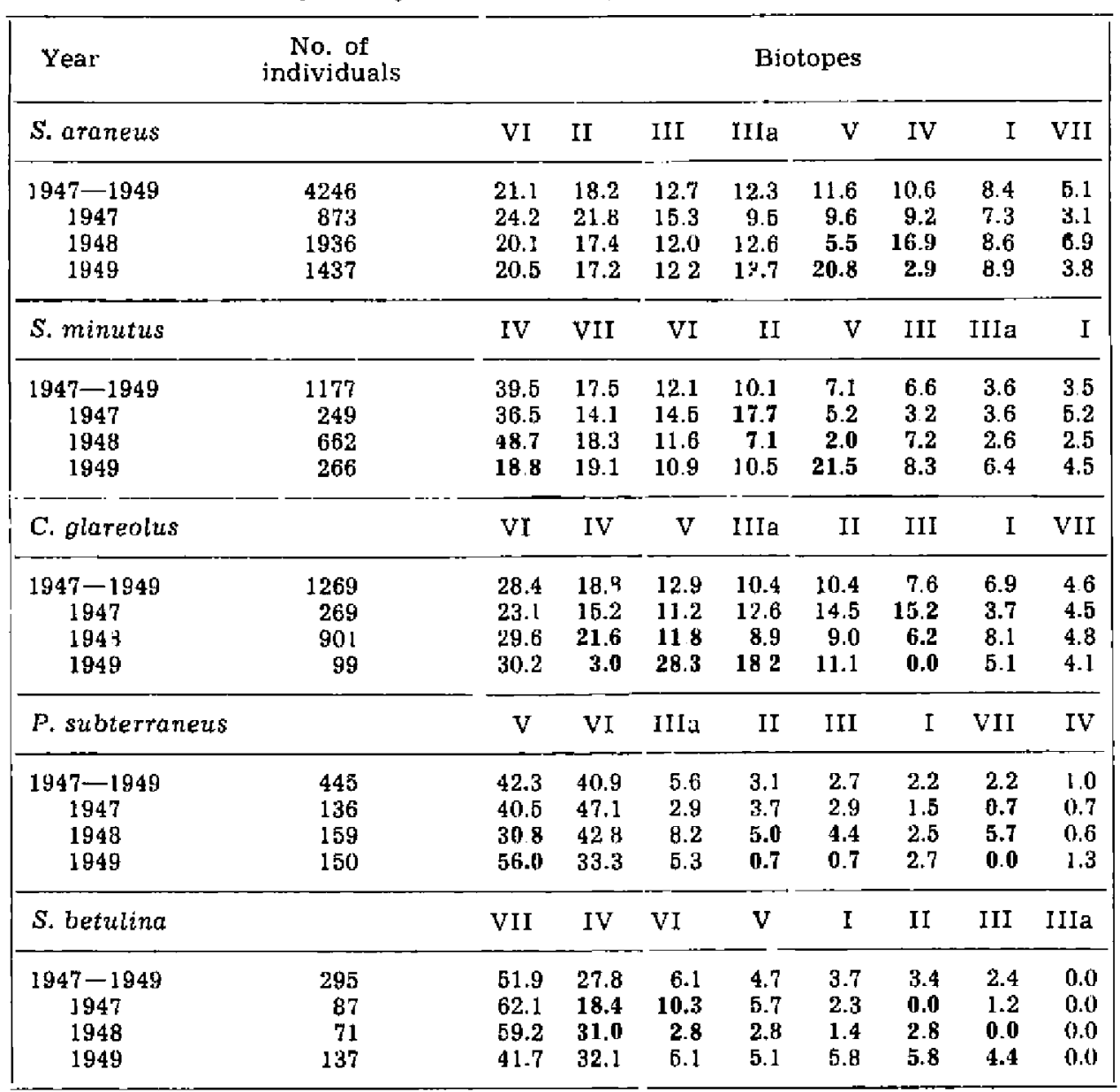

dents in pitfalls (P u c e k, 1969), hence combining the two groups might under-estimate the role of Rodentia in biotopes.

It was found that $S$, araneus is a dominant species in all terrestrial biotopes (Fig. 10); S. minutus also is dominant in moist biotopes (VIII, 
$V I I, I V)$. In these three biotopes thas two species jointly from more than $60 \%$ of the Insectivora group. In Peucedano-Pinetum and Pino-Quercztum biotopes ( $I, I I, I I I$ and $I I I a)$ and in Tilio-Carpinetum (V and VI) $S$. araneus is the sole dominant. The remaining species of Insectivora are not even co-dominants in these biotopes. $N$. fodiens is clearly dominant in an aquatic biotope (IX). The remaining three species (N. anomalus, $S$. araneus, $S$. minutus) co-dominate, the percentage formed by each of these species being below 30\% (Fig. 10).

Relations are more complicated in the case of Rodentia. M. minutus dominates in an aquatic biotope (IX), for which this is simultaneously the native biotope (Fig. 9). Typical hygrophiles such as A. terrestris and $M$. oeconomus co-dominate with this species. The remaining species form only a small percentage of animals found in this biotope.

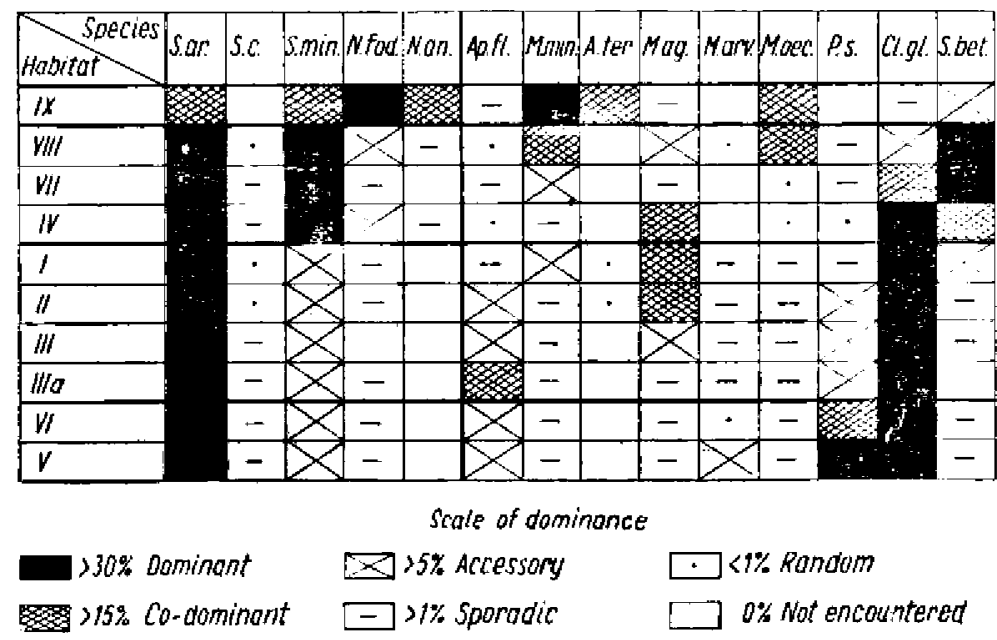

Fig. 10. Percentage of various species (dominance) in Insectivora and Rodentia communities from 1947-1949.

In the group of most biotopes including different habitats the dominant species are S. betulina (VIII and VII) and C. glareolus (IV). In the wettest of these biotopes (VIII), hygrophilous species, such as $M$. minutus and $M$. eoconomus, for which this is simultaneously the joint native biotope, are co-dominants. In Ciraeo-Alnetum (VII) C. glareolus is a co-dominant, the remaining species forming only a small percentage. Pinetum turfosum (IV) possesses, in addition to the dominant C. glareolus, two co-dominant species: $S$. betulina and $M$. agrestis. This is the native biotopes for this last species. The role of $C$. glareolus is remarkable in this biotope. The high degree of preference and dominance of this species in Pinetum turfosum was particularly marked in 1948. This was 
the year of highest numbers for the majority of species of Micromammalia. The red-backed vole exhibited an exceptionally great increase in numbers in this biotope. In 1948 almost five times more individuals of C. glareolus were caught there than in 1947, and therefore the situation

Table 7.

Percentage (domination index) of some species of small mammals in different biotopes from 1947-1949. In each case the sum totals of Insectivora and Rodentia caught in each biotope were taken as $100 \%$, Domination indices differing visibly in suecessive years are boldfaced. Biotopes arranged in order of decreasing dominance of the species in the community.

\begin{tabular}{|c|c|c|c|c|c|c|c|c|}
\hline \multirow{2}{*}{$\begin{array}{c}\text { Year } \\
\text { S. araneus }\end{array}$} & \multicolumn{8}{|c|}{ Biotope } \\
\hline & IIIa & I & III & II & VI & $\mathrm{V}$ & VII & IV \\
\hline $\begin{array}{c}1947-1949 \\
1947 \\
1948 \\
1949\end{array}$ & $\begin{array}{l}88.0 \\
86.7 \\
89.7 \\
86.2\end{array}$ & $\begin{array}{l}87.3 \\
82.1 \\
89.7 \\
87.1\end{array}$ & $\begin{array}{l}85.6 \\
91.7 \\
81.0 \\
87.8\end{array}$ & $\begin{array}{l}84.5 \\
80.4 \\
85.7 \\
86.3\end{array}$ & $\begin{array}{l}82.4 \\
81.6 \\
80.4 \\
85.8\end{array}$ & $\begin{array}{l}82.3 \\
84.0 \\
87.1 \\
80.3\end{array}$ & $\begin{array}{l}47.4 \\
39.2 \\
50.0 \\
46.2\end{array}$ & $\begin{array}{l}44.5 \\
43.7 \\
46.5 \\
34.7\end{array}$ \\
\hline S. minutus & IV & VII & $\mathrm{V}$ & VI & II & III & I & IIIa \\
\hline $\begin{array}{c}1947-1949 \\
1947 \\
1948 \\
1949\end{array}$ & $\begin{array}{l}46.0 \\
49.7 \\
46.4 \\
42.3\end{array}$ & $\begin{array}{l}45.4 \\
50.7 \\
45.1 \\
438\end{array}$ & $\begin{array}{l}13.9 \\
13.0 \\
10.5 \\
15.2\end{array}$ & $\begin{array}{r}13.1 \\
14.5 \\
15.9 \\
8.4\end{array}$ & $\begin{array}{r}13.0 \\
18.5 \\
11.9 \\
9.8\end{array}$ & $\begin{array}{r}12.3 \\
5.5 \\
16.7 \\
11.0\end{array}$ & $\begin{array}{r}10.0 \\
19.1 \\
8.6 \\
8.2\end{array}$ & $\begin{array}{l}7.2 \\
9.6 \\
6.3 \\
7.4\end{array}$ \\
\hline C. glareolus & III & IIIa & II & VI & IV & I & $\mathrm{V}$ & VII \\
\hline $\begin{array}{c}1947-1949 \\
1947 \\
1948 \\
1949\end{array}$ & $\begin{array}{r}60.3 \\
60.4 \\
71.8 \\
0.0\end{array}$ & $\begin{array}{l}59.7 \\
57.6 \\
62.0 \\
54.5\end{array}$ & $\begin{array}{l}56.0 \\
51.0 \\
61.0 \\
42.5\end{array}$ & $\begin{array}{l}62.9 \\
35.8 \\
65.3 \\
30.8\end{array}$ & $\begin{array}{r}47.2 \\
41.4 \\
56.3 \\
4.8\end{array}$ & $\begin{array}{l}43.8 \\
25.0 \\
53.3 \\
20.8\end{array}$ & $\begin{array}{l}32.4 \\
24.8 \\
52.7 \\
15.2\end{array}$ & $\begin{array}{r}23.1 \\
16.4 \\
37.7 \\
5.9\end{array}$ \\
\hline P. subterraneus & $\mathbf{V}$ & VI & IIIa & III & II & I & VII & IV \\
\hline $\begin{array}{c}1947-1949 \\
1947 \\
1948 \\
1949\end{array}$ & $\begin{array}{l}37.1 \\
45.5 \\
24.4 \\
45.7\end{array}$ & $\begin{array}{l}26.8 \\
37.0 \\
16.7 \\
51.6\end{array}$ & $\begin{array}{r}11.3 \\
6.8 \\
10.0 \\
24.2\end{array}$ & $\begin{array}{l}7.4 \\
5.9 \\
9.0 \\
6.7\end{array}$ & $\begin{array}{l}6.0 \\
6.7 \\
6.0 \\
3.8\end{array}$ & $\begin{array}{r}5.0 \\
5.0 \\
2.9 \\
16.7\end{array}$ & $\begin{array}{l}3.9 \\
1.4 \\
7.9 \\
0.0\end{array}$ & $\begin{array}{l}0.8 \\
1.0 \\
0.0 \\
32\end{array}$ \\
\hline S. betulina & VII & IV & $\mathbf{I}$ & III & II & $\mathrm{V}$ & VI & IIIa \\
\hline $\begin{array}{c}1947-1949 \\
1947 \\
1948 \\
1949\end{array}$ & $\begin{array}{l}60.0 \\
74.0 \\
36.8 \\
33.9\end{array}$ & $\begin{array}{r}16.2 \\
16.1 \\
6.3 \\
70.8\end{array}$ & $\begin{array}{r}5.5 \\
5.1 \\
0.7 \\
\mathbf{3 3 . 3}\end{array}$ & $\begin{array}{r}4.4 \\
1.5 \\
0.0 \\
\mathbf{4 0 . 0}\end{array}$ & $\begin{array}{r}4.3 \\
0.0 \\
15.0 \\
30.7\end{array}$ & $\begin{array}{l}2.8 \\
4.1 \\
1.0 \\
3.8\end{array}$ & $\begin{array}{l}2.6 \\
5.5 \\
0.5 \\
7.2\end{array}$ & $\begin{array}{l}0.0 \\
0.0 \\
0.0 \\
0.0\end{array}$ \\
\hline
\end{tabular}

in 1948 was of decisive importance to determining the role of this species in Pinetum turfosum.

C. glareolus is the dominant in the group of biotopes in which pine predominates. In Pino-Quercetum (III) it is the absolute dominant. In the 
poorest biotopes of this group ( $I$ and $I I$ ) $M$. agrestis is a co-dominant. In Pseudo-Quercetum (IIIa), in which species bearing heavy seeds are included in the composition of the tree-stand, the co-dominant is the typical seed-eater $A$. flavicollis. The remaining species form a negligible percentage in Peucedano-Pinetum and Pino-Quercetum. In Tilio-Carpinetum

Table 8.

Preferences (W) and domination (D) of some species of Micromammalia in most densely and least densely settled biotopes from 1947-1949 (jointly).

\begin{tabular}{|c|c|c|c|c|c|}
\hline \multirow{2}{*}{\multicolumn{2}{|c|}{ Species }} & \multicolumn{4}{|c|}{ Biotopes setteled: } \\
\hline & & \multicolumn{2}{|c|}{ most densely } & \multicolumn{2}{|c|}{ least densely } \\
\hline \multirow[t]{2}{*}{ S. araneus } & Biotope & VI & II & VII & IX \\
\hline & $\begin{array}{l}W^{0 / 0} \\
\mathbf{D}^{0 / \%}\end{array}$ & $\begin{array}{l}1.8 .87 \\
82.38\end{array}$ & $\begin{array}{l}16.36 \\
84.50\end{array}$ & $\begin{array}{r}4.56 \\
47.37\end{array}$ & $\begin{array}{r}2.52 \\
19.04\end{array}$ \\
\hline \multirow[t]{2}{*}{ S. minutus } & Bjotope & IV & VIII & IIIa & I \\
\hline & $\begin{array}{l}W \% / \\
D^{0} \%\end{array}$ & $\begin{array}{l}29.11 \\
46.04\end{array}$ & $\begin{array}{l}27.69 \\
38.84\end{array}$ & $\begin{array}{l}2.70 \\
7.24\end{array}$ & $\begin{array}{r}2.57 \\
10.00\end{array}$ \\
\hline \multirow[t]{2}{*}{ A. flavicollis } & Biotope & $\mathrm{VI}$ & $\mathrm{V}$ & IV & VIII \\
\hline & $\begin{array}{l}W^{0} \% \\
D^{0 / 0}\end{array}$ & $\begin{array}{l}31.94 \\
10.16\end{array}$ & $\begin{array}{l}28.24 \\
12.06\end{array}$ & $\begin{array}{l}0.93 \\
0.39\end{array}$ & $\begin{array}{l}0.46 \\
0.35\end{array}$ \\
\hline \multirow[t]{2}{*}{ M. minutus } & Biotope & IX & VIII & IIIa & III \\
\hline & $\begin{array}{l}W^{0 / 0} \\
D^{\%} / 0\end{array}$ & $\begin{array}{l}47.30 \\
40.53\end{array}$ & $\begin{array}{l}17.05 \\
15.44\end{array}$ & $\begin{array}{l}3.10 \\
3.62\end{array}$ & $\begin{array}{l}1.16 \\
1.86\end{array}$ \\
\hline \multirow[t]{2}{*}{ M. agrestis } & Biotope & VI & I & IIIa & VII \\
\hline & $\begin{array}{c}W^{0 / u} \\
D^{0 / u}\end{array}$ & $\begin{array}{l}40.53 \\
29.98\end{array}$ & $\begin{array}{l}14.40 \\
17.95\end{array}$ & $\begin{array}{l}2.67 \\
2.74\end{array}$ & $\begin{array}{l}1.87 \\
4.32\end{array}$ \\
\hline \multirow[t]{2}{*}{ P. subterraneus } & Biotope & $\mathrm{V}$ & VI & IV & VIII \\
\hline & $\begin{array}{l}W \% \\
\mathrm{D}^{*} \%\end{array}$ & $\begin{array}{l}41.97 \\
37.14\end{array}$ & $\begin{array}{l}40.63 \\
26.80\end{array}$ & $\begin{array}{r}0.89 \\
11.31\end{array}$ & $\begin{array}{l}0.67 \\
4.98\end{array}$ \\
\hline \multirow[t]{2}{*}{ C. glareolus } & Biotope & VI & IV & VIII & IX \\
\hline & $\begin{array}{l}\text { W\%o } \\
D^{0 \%}\end{array}$ & $\begin{array}{l}27.30 \\
62.89\end{array}$ & $\begin{array}{l}18.17 \\
32.41\end{array}$ & $\begin{array}{r}2.74 \\
12.63\end{array}$ & $\begin{array}{l}0.76 \\
3.32\end{array}$ \\
\hline \multirow[t]{2}{*}{ S. betulina } & Biotope & VII & VIII & II & III \\
\hline & $\begin{array}{l}W \% \\
D \%\end{array}$ & $\begin{array}{l}35.92 \\
60.01\end{array}$ & $\begin{array}{l}25.82 \\
38.60\end{array}$ & $\begin{array}{l}2.36 \\
4.27\end{array}$ & $\begin{array}{l}1.64 \\
4.35\end{array}$ \\
\hline
\end{tabular}

$(V$ and VI) $C$. glareolus and $P$. subterraneus predominate, the latter species co-dominanting in VI. Although $A$. flavicollis has its optimum living conditions here, its numbers are never equal of the two above-mentioned species. It is possible that the percentage of this species has been slightly under-estimated here on account of the fact that its repre- 
sentatives were found to jump out and escape from the traps (A d a mc z ew ska, 1959). This possible underestimation is not, however, very great, since analysis of the composition of rodent communities in Tilio-Carpinetum made by other methods does not reveal numerical predominance of this species over C. glareolus.

Analysis of variation in the dominance index from 1947-1949 (Table 7) shows that its amplitudes are far greater in Rodentia than in Insectivora. This is accounted for by the fact that far greater fluctuations occur in the numbers of rodents than of insecetivores. Comparison of Fig. 9 and 10 reveals that it is only in certain cases that the various species are quantitative dominants in their native biotopes. In the great majority of cases the preference and dominance indices do not coincide (Table 8 ). In the case of some species their role even in native biotopes is small ( $A$. flavicollis), while in others the role of the species is very great even in non-native biotopes ( $S$. araneus, $S$. minutus). Only in some cases do the preference and dominance indices exhibit a certain numerical coincidence ( $M$. minutus, $M$. agrestis). Changes in ecological factors in different years do not evoke uniform quantitative changes in all species of Micromammalia, hence reciprocal quantitative relations between the various components of communities differ in different years.

\subsection{Relative Density of Insectivora and Rodentio}

The sum of habitat conditions in different biotopes given a certain pattern of ecological niches which, to a greater or lesser degree, determines the percentage of the various species of mammals or their groups in the biotopes examined. The average annual numbers of small mammals have been calculated for non-forest biotopes from two years data, and from forest biotopes from three years data (Fig. 11). The figure illustrates the relative density of Micromammalia in different biotopes, and in turn defines the potential capacities of each biotope for supporting more or less numerous Micromammalia populations.

The greatest average annual abundance of Micromammalia is shown by Tilio-Carpinetum (VI), then Caricetum (VIII) and Pinetum turfosum (IV). Relations for Insectivora and Rodentia form a slightly different pattern. The greatest numbers of rodents were found in Tilio Carpinetum stachyetosum silvaticae (VI). This is a biotope producing the greatest seed biomass (Table 4) which form the chief component of the food of the dominant rodents. Similar relations prevail in Tilio-carpinetum typicum $(V)$. Seed production here is, however, lower and hence the numbers of rodents are also smaller. The large number of rodents in Pinetum turfosum (IV) is difficult to explain, especially as it is chiefly data from 1948 which is responsible for this high average figure. Catches in this 
biotope were disproportionately great in 1948 in comparison with other years and with other biotopes in the some year. In the Circaeo-Alnetum biotope the low percentage of $C$. glareolus and predominance of less numerous hygrophilous species resulted in the figure for Rodentia being fairly low. The smallest number of rodents was caught in the Peucedano-Pinetum and Pino-Quercetum biotopes. The small numbers of Rodentia in Pseudo-Quercetum (IIIa), in which seed production is high, is fairly characteristic. It would appear that the low density is due to the varying amounts of seed produced in successive years by the oak which

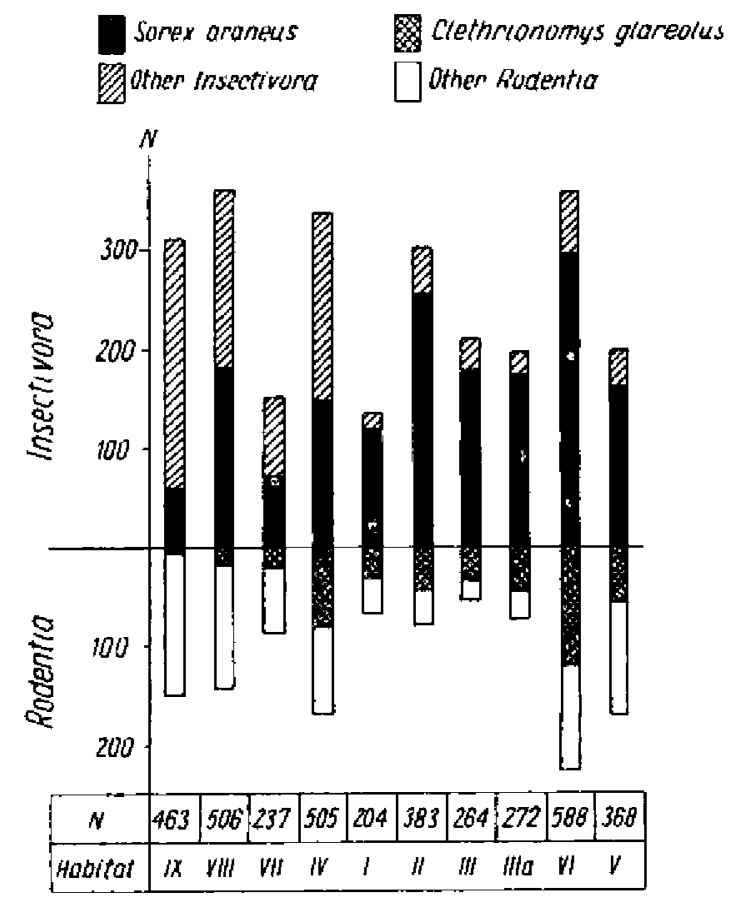

Fig. 11. Mean numbers of small mammals during year for period 1947-1949.

is the chief seed producer there, and to the extreme temperatures prevailing there during the winter period (Fig. 6-8). This may lead to low numbers of mammals surviving to reproduce in spring.

The density relations found in the case of Insectivora follow a different pattern. The biotope most numerously occupied, as in the case of $R_{0}$ dentia, is Tilio-Carpinetum stachyetosum silvaticae (VI). The second in order, from among the relatively dry biotopes, is Peucedano-Pinetum (II). It may be that the temperatures prevailing in the ground level air layer may influence this, particularly during the winter period (Fig. 8) and also 
the fairly high biomass of invertebrates. In the remaining biotopes, quantitative relations are more or less balanced. In moist biotopes the numbers of Insectivora are fairly high, Circaeo-Alnetum being the least densely settled biotope.

With respect to density of Micromammalia, the biotopes examined can be arranged in the following order: VI, VIII, IV, IX, II, V, IIIa, III, VII, I. This order does not reflect the true productivity of the Micromammalia communities in these biotopes, but is the result of relative density of the various species and their activity.

\section{MICROM AMM ALIA COMMUNITIES}

\subsection{Similarities Between Communities}

The varied biotope preferences exhibited by different species of Micromammalia and the different species dominance in different biotopes causes differentiation of the communities of small mammals and different degrees of similarity between the groups.

A. Czeka now ski diagram (Fig. 12) was drawn up to find the reciprocal similarities. The similarity indices were defined by means of Sor ens en's equation:

$$
\mathrm{P}=\frac{2 c}{a+b} \cdot 100 \%,
$$

where

$a$ - number of species in mammal community I,

$b$ - number of species in mammal community II,

$c$ - number of species common to the two communities compared.

The lowest dominance index for the two communities compared was taken as a common element. The sum total of these values gave value $P$ in $\%$. This index defines similarity of dominance regardless of the density of species in the mammal communities compared.

Three groups of communities are differentiated on the diagram (Fig. 12a). The first of these covers the community in the Hylaquarium biotope. Outstandingly hygrophilous species dominate in its composition and consequently there is little similarity between the community from this biotope and other communities from other biotopes and their somewhat distant phytosociological relationships, the humidity factor outweighed these in importance, so that there were considerable similarities in the communities of small mammals. In addition to S. araneus, $S$. minutus is co-dominanat in the communities of these biotopes. The similarities of this group of communities to others do not exceed $60 \%$. Only the community from Pinetum turfosum, owing to the greater percentage of C. glareolus, is slightly more similar to the community from the poor 
Peucedano-Pinetum biotope. The third group exhibits certain internal differences. It is possible to distinguish a sub-group of communities from Peucedano-Pinetum and Pino-Quercetum and a subgroup from the Tilio-Carpinetum biotopes. This differentiation is due to the far smaller percentage of $S$. araneus in the Tilio-Carpinetum communities and the greater percentage of $P$. subterraneus in these communities.

When Fig. 12a and Fig. 4 are compared it is clear that animal communities are to a certain extent determined by the plant associations. The groups of biotopes (distinguished according to their floristic composition) on the two diagrams correspond to groups of biotopes defined according to the composition of the Micromammalia communities. The only exception is Circaeo-Alnetum (VII), which together with Tilio-Carpinetum ( $V$ and $V I$ ) belongs to one phytosociological class Querco-Fagetea B r. - B l. et Vlieg. 1937, while its Micromammalia community is similar to

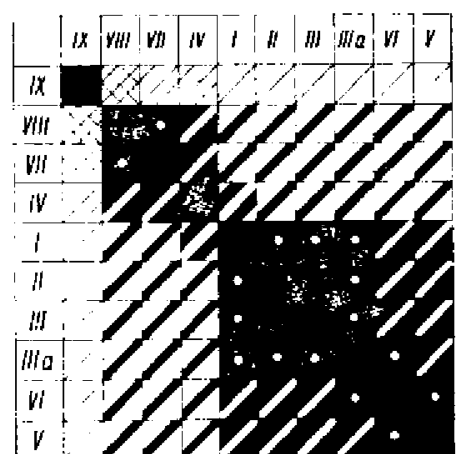

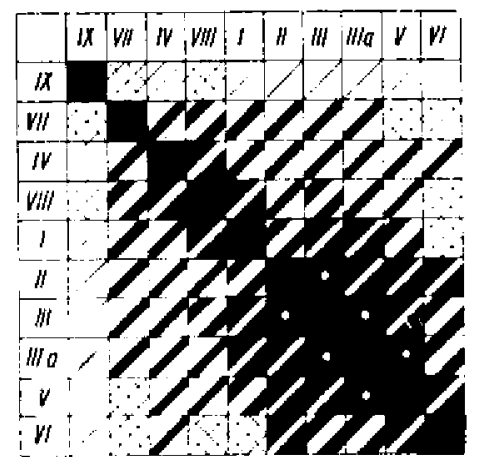

b

Fig. 12. Diagram of similarities between small mammal communities for 1947-1949 (jointly) according to: (a) quantitative participation of different species, (b) quantitative participation. Scale of similarities expressed in percentage (as for Fig. 4).

communities in the other humid biotopes, which from the phytosociological aspect are allocated to other classes.

The Micromammalia communities from the different groups of biotopes can be defined according to dominant species as follows:

Group I - Biotope IX $-N$. fodiens, $S$. minutus, $M$. minutus.

Group II - Biotope VIII and VII - S. araneus, S. minutus, S. betulina. Biotope IV $-S$, araneus, S. minutus, C. glareolus.

Group III - Biotope I, II, III and IIIa - S. araneus, C. glareolus. Biotope $V$ and $V I-S$. araneus, $C$. glareolus, $P$. subterraneus.

When calculating the index of dominance similarity (Fig. 12a) the relative density of Micromammalia in different biotopes was converted to a common denominator $(=100 \%)$. Fig. $12 \mathrm{~b}$ shows the quantitative 
relations between species. Despite certain internal shifts in the order of biotopes in different groups, the quantitative indices of similarity did not cause shifts of different biotopes to other groups. Although the picture is less clear, the pattern of groups of communities and their reciprocal similarities are analogous to those given in Fig. 12a. Only similarity with respect to dominance will therefore be considered in further discussion.

Dominance indices and percentage of components of the communities were determined from the longest possible period of time within the comparable period 1947-1949. The longer the period, the more correctly calculated the average dominance value for the different species (Fig. 13). The similarity of the percentage composition of the Micromammalia community in Peucedano-Pinetum (II) in different years to the composition of the community defined on the basis of long-term captures takes

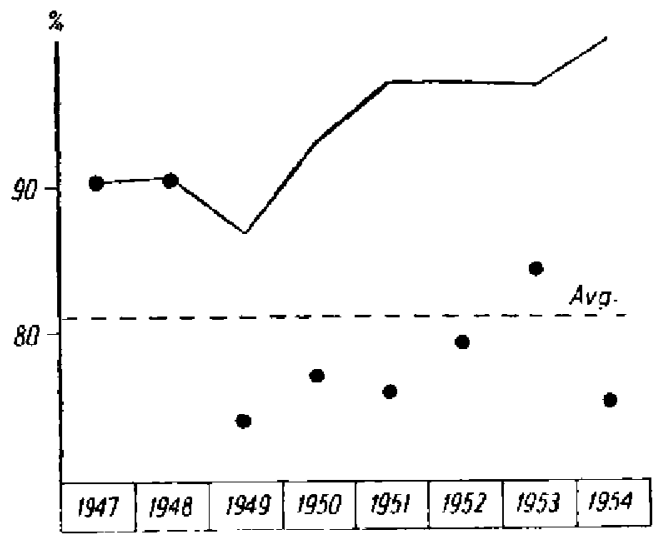

Fig. 13. Similarity of percentage composition of Micromammalia community in different years to percentage composition of community for period 1947-1949 jointly (dots) and cumulated values of similarity (curve). Data for Peucedano-Pinetum forest association (II).

different values. The average value does not greatly exceed $80 \%$. When analysing accumulated material it was found that with an increasing number of years the composition of the community becomes increasingly similar to the long-term composition (from 8 years). The decrease in the curve of similarity in 1949 is fairly characteristic. The composition of the community that year differed most markedly from the average value as the of an abrupt drop in the numbers of Rodentia. The curve representing three-year material in that year did not fall much below $90 \%$. It is clear from this that even considerable alteration of the composition of the community in a given year does not greatly affect the correct definition of its true composition, as the material covers a period of several years. Hence the composition of communities from different biotopes 
defined on the basis of material from 1947-1949 does not differ greatly from the average for several years.

A dominance spectrum was made for the communities examined (Fig. 14), adhering to the same order of biotope as in the diagram of similarity (Fig. 12). In the communities of Micromammalia for the biotopes $I, I I$, $I I I, I I I a, V$ and $V I$ the absolute dominance of $S$. araneus is distinct, its predominance in the Peucedano-Pinetum and Pino-Quercetum being

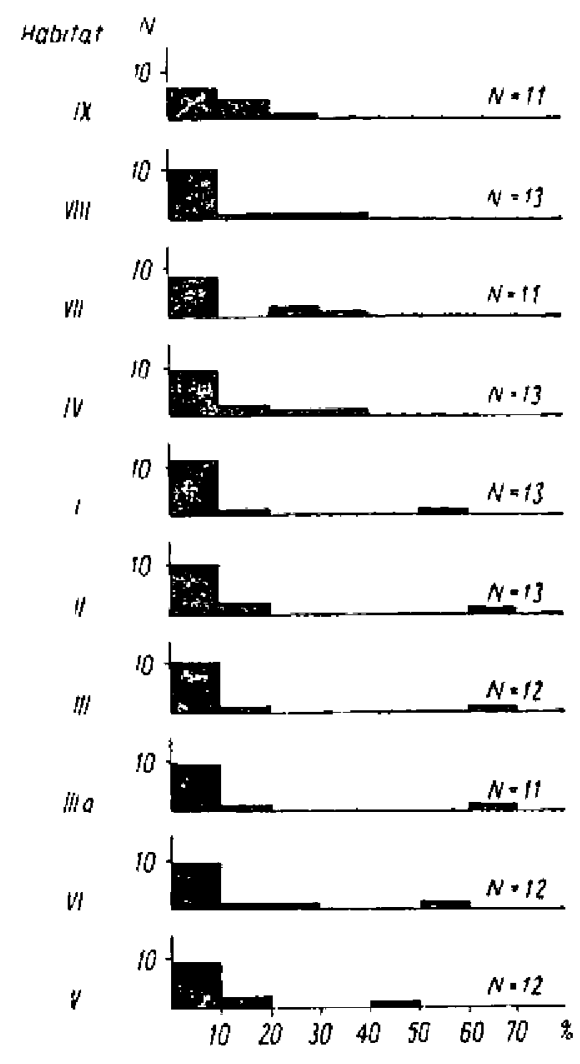

Fig. 14. Participation of species in study biotopes in classes of percentage of individuals in general numbers of mammals.

greater than in Tilio-Carpinetum. In principle there is no absolute dominant in the communities of moist biotopes. Hylaquarium (IX) possesses the most balanced dominance relations. In terrestrial biotopes the great majority of the species have a dominance andex with limits of $0-10 \%$. The role of these species in the communities and their production of biomass is also small.

The different habitat conditions in the biotopes examined form the cause, not only of different dominance indices of the species, but also of the general proportions between Insectivora and Rodentia treated jointly. An annual spectrum of Micromammalia communities was analysed (Fig. 
15). In each biotope there is a distinct predominance of Insectivora, which may be due to their greater ease of capture in pitfalls. The proportions between different biotopes, however, point to certain significant differences in the percentage spectrum of the communities.

Tilio-Carpinetum (VIII) is distinguished by a relatively high percentage of Rodentia, seed food production being high there, and this accounts for the greater percentage of "seed-eaters" in these biotopes. Also, on account of the considerable number of rhizomic plants, the percentage of $P$. subterraneus is high there. In biotopes in which pine predominantes the

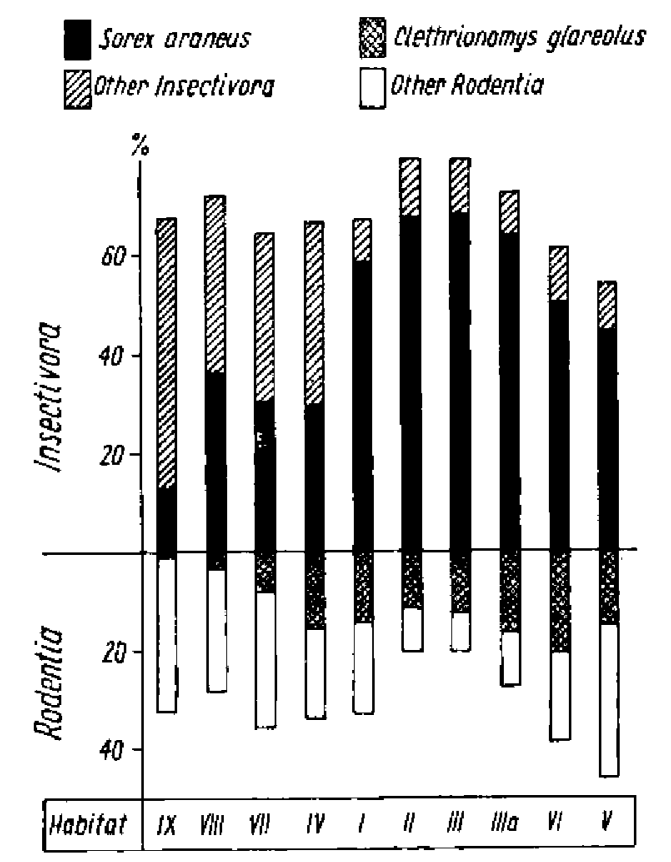

Fig. 15. Percentage of Insectivora and Rodentia in study biotopes for period 1947-1949.

percentage of rodens is highest in the poor biotope Peucedano-Pinetum $(I)$, in which the annual stand of biomass is fairly evenly distributed over the whole of the year because of the abundance of hardy shrubs (e.g. Vaccinium sp.). There is a slightly smaller percentage of rodents in Pseudo-Quercetum, in which abundant seed production does not occur every year, so that the index of the percentage of Rodentia is the resultant of good and poor seed years.

In moist terrestrial biotopes the percentage of rodents is higher than in Peucedano-Pinetum and Pino-Quercetum, but lower than in Tilio- 
-Carpinetum. The percentage of $C$. glareolus is reduced in favour of hygrophilous rodents.

Hylaquarium has an annual spectrum similar to moist terrestrial associations, except that here the percentage of species which are dominants in the terrestrial communities drops to a minimum value.

\subsection{Variations in Communities from 1947-1949}

Quantitative fluctuations in the different components of the epigeic Micromammalia communities contribute to variations in preference and dominance indices, and result in the occurrence of different degrees of

Table 9.

Similarities of small mammals communities (in $\%$ ) in forest biotopes.

\begin{tabular}{|c|c|c|c|c|}
\hline Biotope & 1947 \& 1948 & 1947 \& 1949 & 1948 \& 1949 & $\begin{array}{c}\text { Difference } \\
\text { Max.-Min. }\end{array}$ \\
\hline I & 79.6 & 71.7 & 65.0 & 14.5 \\
II & 90.5 & 76.0 & 804 & 14.5 \\
III & 89.2 & 71.0 & 77.6 & 18.2 \\
IIIa & 91.0 & 72.7 & 79.6 & 18.3 \\
IV & 91.6 & 68.4 & 63.9 & 27.7 \\
V & 76.7 & 76.8 & 68.1 & 8.7 \\
VI & 79.7 & 79.7 & 68.0 & 11.7 \\
VII & 69.9 & 84.4 & 75.0 & 14.5 \\
\hline
\end{tabular}

Table 10.

Ratio of Insectivora to Rodentia.

\begin{tabular}{|c|ccc|c|}
\hline Biotope & 1947 & 1948 & 1949 & $\begin{array}{c}\text { Total } \\
1947-1949\end{array}$ \\
\hline IX & - & 1.38 & 2.61 & 2.08 \\
VIII & - & 2.86 & 2.29 & 2.55 \\
VII & 0.94 & 2.35 & 1.75 & 1.79 \\
IV & 1.85 & 2.00 & 1.90 & 1.96 \\
II & 1.95 & 1.36 & 6.08 & 2.04 \\
II & 3.16 & 2.95 & 11.00 & 3.91 \\
III & 2.15 & 3.45 & 13.27 & 3.81 \\
IIIa & 1.59 & 2.10 & 6.94 & 2.69 \\
VI & 1.49 & 1.18 & 3.52 & 1.60 \\
V & 0.83 & 0.61 & 2.04 & 1.18 \\
\hline
\end{tabular}

internal similarity of communities over a period of several years (Table 9). The differences between communities in the same biotopes in different years are fairly considerable. In the majority of communities the minimum similarity values oscillate between 60 and $70 \%$. In most of the 
biotopes the similarities of communities between the year preceding peak numbers (1947) and the peak year (1948) are greater than between the other years of the study period. But the greatest differences occur between the year of decreasing numbers of Rodentia (1949) and the other years. This is the result of significant alterations in dominance relations during the marked reduction in rodent numbers (Table 10). The greatest decreases occur in dry and trophically poor biotopes; hence in 1949 in $I$, $I I, I I I$ and $I I I a$ there is a much greater preponderance of Insectivora than in the other biotopes. In moist biotopes the decrease in Rodentia was much smaller than in Insectivora and hence the indices of the ratio in Insectivora to Rodentia are lower in 1949 than in the peak year of Micromammalia (1948). Variation in these indices in the long-term point to the need to analyse the composition of Micromammalia communities on the basis of material obtained from a large number of years.

Table 11.

Similarities in percentage composition of small mammal communities in particular years to composition of communities defined according to summarized data for whole study period (1947-1949).

\begin{tabular}{|c|c|c|c|}
\hline Biotope & 1947 & 1948 & 1949 \\
\hline & & & \\
I & 87.1 & 86.7 & 77.2 \\
II & 90.6 & 94.1 & 84.8 \\
III & 87.5 & 92.8 & 83.4 \\
IIIa & 97.2 & 93.9 & 839 \\
IV & 95.0 & 94.7 & 69.0 \\
V & 87.9 & 79.6 & 89.5 \\
VI & 90.2 & 87.4 & 79.9 \\
VII & 81.8 & 87.4 & 87.6 \\
VIII & - & 80.5 & 86.4 \\
IX & - & 87.9 & 94.1 \\
\hline
\end{tabular}

A check was made to see to what degree the composition of mammal communities in a given year differs from the composition obtained by results of long-term trapping (Table 11). The calculated values here higher than in Table 9. The composition of the community, defined on the basis of material from one year, differs from the average composition obtained from long-term trapping far less than it differs from the composition of this same community in different years. The most significant difference is that between the long-term composition and the 1949 community in Pinetum turfosum. There may thus be cases in which a one-year analysis of the composition of a community does in fact give a false picture.

The variation found in communities in the long term also cause variation in similarity indices between communities in different years (Fig. 
16). The same order has been retained in the diagrams as in Fig. 12; that is, the order accords with the pattern resulting from long-term trapping (1947-1949). In the majority of biotopes groups of communities discussed in the preceding sections of this paper were clearly differentiated in 1947, the year preceding the peak numbers of Micromammalia. The peak year (1948) appears at first glance to give a somewhat confused picture. If data from this year only had seen analysed it would have been difficult to speak of significant differences between communities from different biotopes. In 1949, howerer, the year of decrease in the numbers of Micromammalia, there is distinct division into three basis groups of biotopes: (1) aquatic biotope, (2) moist and wet biotopes and (3) the Peucedano-Pinetum, Pino-Quercetum and Tilio-Carpinetum biotopes. In 1949 these three groups exhibit minimum similarity to the other groups, and simultaneously greater internal consistency than in other years. This pattern of relations can be explained by the different preferences of the species examined in the different years of this period.

1947

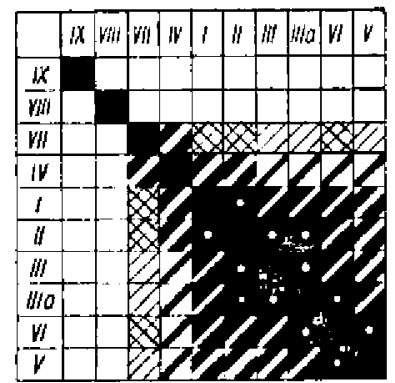

1948

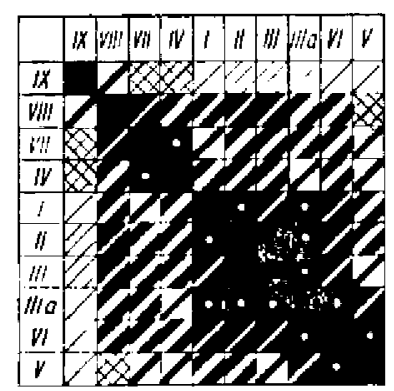

1949

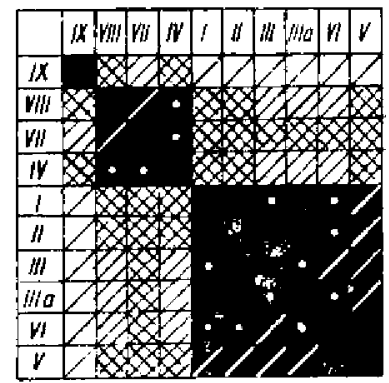

Fig. 16. Diagrams of similarities of small mammal communities in 1947, 1948 and 1949 according to percentage of different species. Similarity scale as for Fig. 4.

In a year of maximum (1948) the favourable conditions in all the biotopes led to increased percentages of different species of mammals, even in biotopes less readily occupied. Migration may also take place from overcrowded biotopes to those in which the density of the given species is usually slight, and where the favourable circumstances in the given year permit of an increase in population density. As a result the dominance relations are slightly altered, the degree of attachment to biotopes lassened and similarities between the communities of different biotopes are greater. In the year when the numbers of Micromammalia decreased the deterioration in habitat conditions leads primarily to migration from different biotopes of species which do not find optimum living conditions there. These species may also disappear through mortality. Thus in years 
unfavourable to Micromammalia individual species occur most numerously in the biotopes most favourable to them (that is, in their native biotopes). In unfavourable years those species least affected by factors contributing to population decrease in the given biotope dominate in the composition of the community of that biotope. During this period the communities of different biotopes or groups of biotopes differ most from each other and therefore the $\mathrm{Czekanowski}$ diagram emphasises these differences most distinctly. Confirmation of this is supplied by Table 12. Except for $S$. minutus, in the year of minimum numbers the

Table 12.

Percentage of some Micromammalia in five most densely settled biotopes in year of maximum and minimum numbers (for 1948 and 1949).

\begin{tabular}{|l|c|c|}
\hline \multicolumn{1}{|c|}{ Species } & $\begin{array}{c}\text { Peak } \\
\text { year }\end{array}$ & $\begin{array}{c}\text { Crash } \\
\text { year }\end{array}$ \\
\hline & & \\
S. araneus & 59.0 & 73.9 \\
S. minutus & 82.8 & 74.1 \\
N. fodiens & 88.7 & 98.5 \\
A. flavicollis & 88.2 & 94.4 \\
P. subterraneus & 90.1 & 95.4 \\
C. glareolus & 77.6 & 84.9 \\
S. betulina & $\mathbf{8 7 . 4}$ & 95.4 \\
\hline
\end{tabular}

Spring

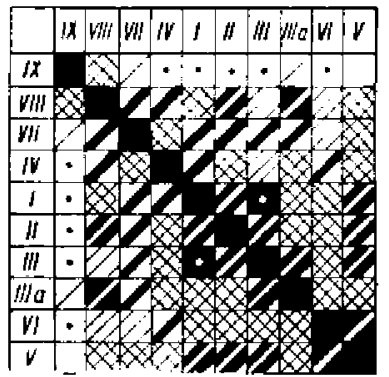

summer

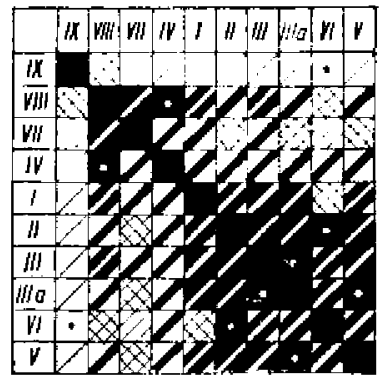

Autumn

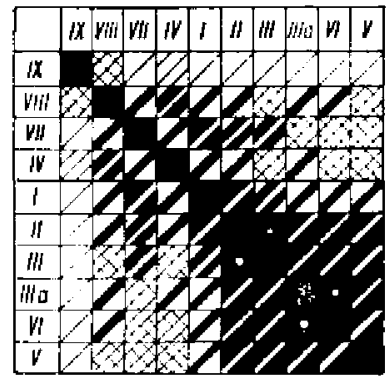

Fig. 17. Diagrams of similarity of small mammal communities in spring, summer and autumn for $1947-1949$ according to percentage of different species. Similarity scale as for Fig. 4.

various species exhibit a greater degree of attachment to native biotopes. This phenomenon can be observed even in the case of such eurybionts as $S$. araneus and $C$. glareolus, which disappear from less favourable biotopes during a year of minimum numbers.

A diagram was also prepared (Fig. 17) of the similarity of communities from the seasonal viewpoint. The divisions used were: spring (MarchMay), summer (June-August), and autumn (September-November). 
The winter period (December-February) was not analysed, as winter captures were not comparable because of the trapping method used.

The autumn period gives the most compact groups of mammal communities, since the various species occupied chiefly native biotopes. A less distinct picture is observed in summer. In spring, however, similarities between communities are slight, although markedly greater similarities occur between communities closer to each other then between communities of mammals from biotopes with different habitat conditions.

\subsection{Long-term Variations in Mammal Communities}

Trapping of small mammals in Peucedano-Pinetum (II) was continued until the autumn of 1955. From 1947-1949 variations in numbers of different species were observed to tend in the same direction as variations in
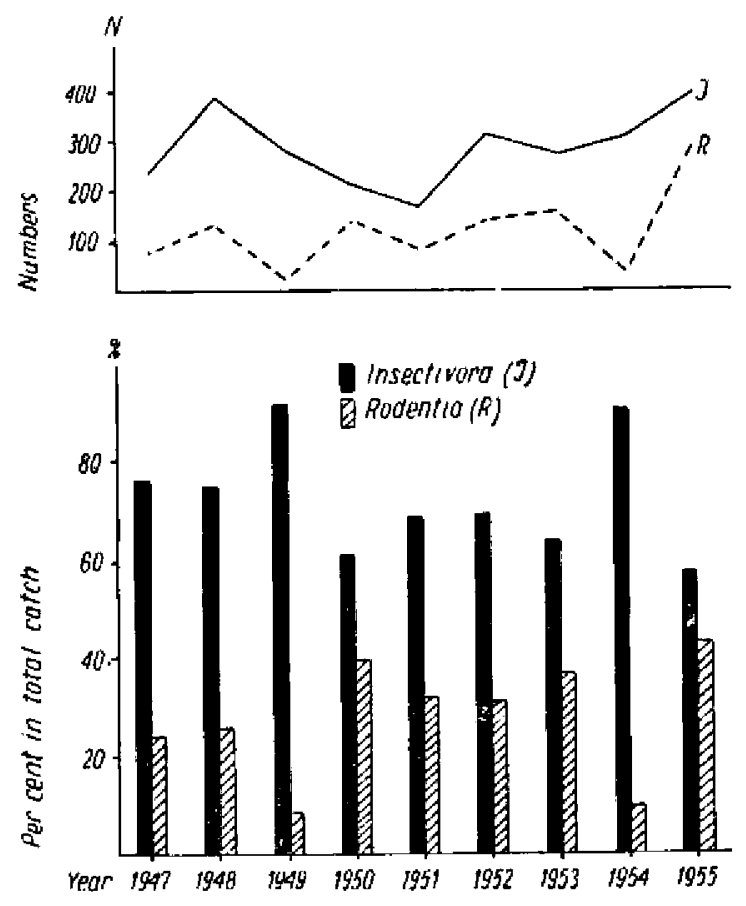

Fig. 18. Variations in numbers and percentage spectrum of Micromammatia community in Peucedano-Pinetum (II) for 1947-1955.

the majority of the other biotopes. Long-term fluctuation in numbers in this biotope can therefore be considered as representative of all biotopes. Variations in the numbers of Insectivora are slight, while numbers of Rodentia fluctuate markedly (Fig. 18). In the case of Insectivora there 
were two distinct peaks in numbers during the study period, in 1948 and 1955. There was also only one clearly depressive year (1951).

In the case of Rodentia the curve of numbers has more peaks, in the summers of $1948,1950,1953$ and 1955 . The diagram also shows clearly the character of declines in the numbers of Insectivora, for which decreases in number after the peaks are slight, and for Rodentia, for which these declines are abrupt, particularly in 1949 and 1954. Comparison of the two curves of numbers reveals the absence in some periods of parallel variations in numbers of Insectivora and Rodentia (1949-1950, 1952-1953, 1953-1954). The years 1948 and 1955 are, however, characteristic here. In these years there is coincidence in the peak numbers of both groups of mammals. Despite the divergent patterns of fluctuations in the remaining years it may be deduced that there are certain habitat factors creating optimum conditions at the same time for the groups of Micromammalia.

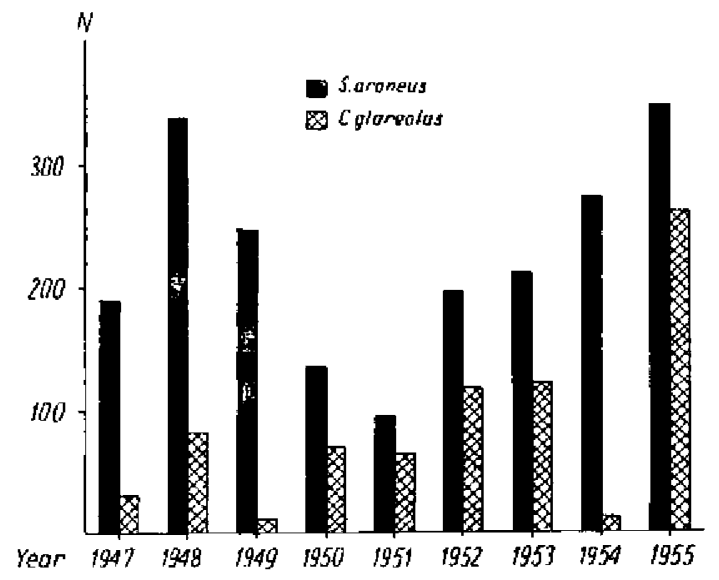

Fig. 19. Dynamics of Sorex araneus and Clethrionomys glareolus in Peucedano-Pinetum (II) for period 1947-1955, as shown by trapping success.

As a result of the frequent but not uniform changes in the numbers of small mammals and the different rates of these fluctuations the dominance spectrum of the community also varies from year to year (Fig. 18). In spite of the general predominance of Insectivora, a very low percentage of Rodentia occurs only during the periods in which the peak of numbers of rodents is followed by an abrupt decrease (1949 and 1954) in other years the oscillations are slight.

Analysis was made of variations in numbers for the two dominants in biotope II (Fig. 19). In the case of S. araneus, after a peak in 1948 numbers gradually decreased until 1951 . Thereafter, there was a distinct increase in numbers until a second peak occurred in 1955 . With C. glareo- 
lus, after a peak in 1948 there was an abrupt drop in numbers in 1949, and then an increase lasting until 1953. The following year (1954) there was again a crash in numbers. The peak of numbers in 1955 exceeded those in all other years of the study period, and coincide with the peak of $S$. araneus.

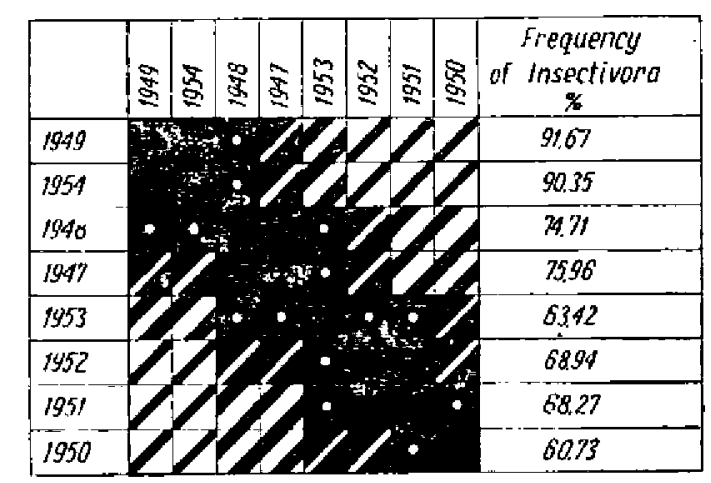

Fig. 20. Diagram of similarities of small mammal communities in Peucedano-Pinetum $(I I)$ between different years for period 1947-1954 according to percentage of different species. Similarity scale as for Fig. 4.

Table 13.

Similarity of percentage composition of small mammals community $(S)$ in Peucedano-Pinetum (II) defined from different trapping periods as compared with pooled data for 1947 - -1949 .

\begin{tabular}{|c|c|c|c|c|c|c|c|}
\hline \multicolumn{2}{|c|}{ One-year periods } & \multicolumn{2}{|c|}{ Two-year periods } & \multicolumn{2}{|c|}{ Th-ee-year periods } & \multicolumn{2}{|c|}{ Four-year periods } \\
\hline years & $s$ & Years & $s$ & Years & $s$ & Years & $S$ \\
\hline $\begin{array}{l}1947 \\
1948 \\
1949 \\
1950 \\
1951 \\
1952 \\
1953 \\
1954\end{array}$ & $\begin{array}{l}90.4 \\
90.5 \\
74.2 \\
77.1 \\
76.0 \\
79.4 \\
84.4 \\
75.4\end{array}$ & $\begin{array}{l}1947-48 \\
1948-49 \\
1949-50 \\
1950-51 \\
1951-52 \\
1952-53 \\
1953-54\end{array}$ & $\begin{array}{l}90.8 \\
85.7 \\
89.9 \\
78.8 \\
79.7 \\
86.8 \\
91.8\end{array}$ & $\begin{array}{l}1947-49 \\
1948-50 \\
1949-51 \\
1950-52 \\
1951-53 \\
1952-54\end{array}$ & $\begin{array}{l}87.4 \\
91.8 \\
91.2 \\
80.8 \\
84.5 \\
95.6\end{array}$ & $\begin{array}{l}1947-50 \\
1948-51 \\
1949-52 \\
1950-53 \\
1951-54\end{array}$ & $\begin{array}{l}93.0 \\
96.4 \\
90.0 \\
64.9 \\
92.9\end{array}$ \\
\hline Avg. & 80.9 & Avg- & 86.2 & Avg. & 88.6 & Avg. & 91.7 \\
\hline
\end{tabular}

The curve of total numbers of both Insectivora and Rodentia (Fig. 18) is more complicated than those of dominants (Fig. 19). For instance, the overall decrease in numbers of Insectivora in 1955 is not evident in S. araneus similarly, decrease in total numbers of Rodentia in 1951 is not the result of any great changes in the numbers of C. glareolus. More exact analysis show that the variations in chosen periods are not syn- 
chronous in all species, and this affects the fluctuations of Insectivora and Rodentia treated jointly.

As the result of different patterns of fluctuation in the numbers of the various components of the communities, the similarity of the Micromammalia comunity also varies from year to year (Fig. 20). The least similarity occurs between years in which the percentages of the different elements in the community (species) or of groups of elements (Insectivora and Rodentia) differ considerably from each other. At one extreme in the diagram there are years with marked prodominance of insectivores over rodents and, at the other extreme, years with far smaller predominance. The order of years on the diagram corresponds to the decreasing role of the Insectivora, except that when comparing the community all elements of the community were taken into consideration. Hence the order of the years has two exceptions to the curve of decrease in the

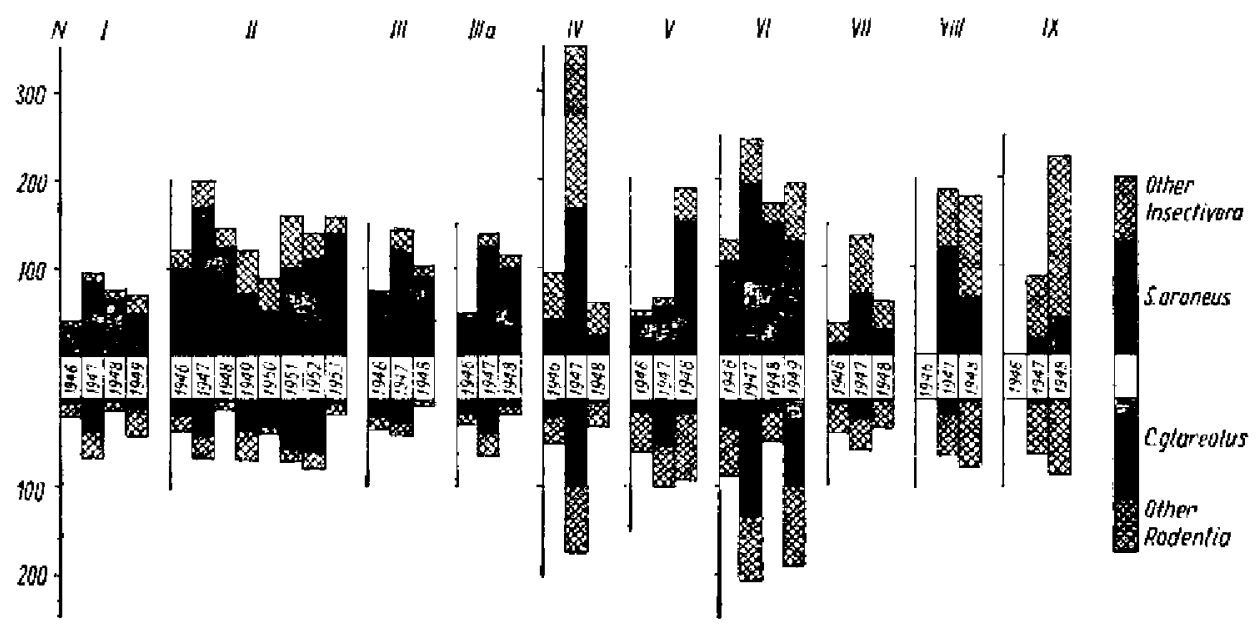

Fig. 21. Trapping dynamies of mammals in 10 biotopes for period 1947-1954.

role of Insectivora (1948 and 1953). The longer the analysis period the more correct the definition of the physionomy and structure of the community, with the variations given above (Table 13).

\subsection{Variations in Captures of Micromammalia and the character of fluctuations found in Insectivora and Rodentia}

During the study period analysed investigation was made of the trapping dynamics of Micromammalia in all biotopes (Fig. 21). In addition to the combined numbers of Insectivora and Rodentia the trapping values for the two dominants ( $S$, araneus and $C$. glareolus) were also given. It 
is clear from the diagrams that the direction taken by variations in numbers in forest biotopes was uniform. The peak year during the period 1947-1949 was 1948. Only the numbers of Insectivora in Tilio-Carpinetum typicum $(V)$ were greater in 1949 than in 1948. For Rodentia, 1949 was a year of low numbers in all the biotopes. There was continued decrease in the numbers of Insectivora in biotopes $I$ and $I I$ in 1950. In biotope VI, on the other hand, only the dominant species exhibited decrease, while the other species of Insectivora increased their numbers slightly. There was also increase in the numbers of Rodentia caught in all there biotopes in 1950. In the non-forest biotopes (VIII and IX) relations followed a slightly different pattern, and depend to a great extent on the

Table 14.

Yearly variations in numbers of small mammals in forest biotopes (I-VII).

\begin{tabular}{|l|r|r|r|}
\hline \multicolumn{1}{|c|}{ Species } & 1947 & 1948 & 1949 \\
\hline S. araneus & 873 & 1936 & 1447 \\
S. caecutiens & 22 & 47 & 30 \\
S. minutus & 249 & 662 & 266 \\
N. fodiens & 21 & 74 & 75 \\
N. anomalus & - & 5 & 6 \\
\hline Insectivora & 1165 & 2719 & 1824 \\
\hline A. flavicolis & 44 & 132 & 35 \\
M. minutus & 18 & 2 & 32 \\
A. terrestris & -98 & 1 & 1 \\
M. agrestis & 307 & 19 \\
M. arvalis & 26 & 15 & 28 \\
M. oeconomus & 136 & 199 & 8 \\
P. subterraneus & 269 & 901 & 99 \\
S. glareolus & 87 & 71 & 137 \\
S. betulina & 708 & 1547 & 509 \\
\hline Rodentia & 1873 & 4266 & 2333 \\
\hline Micromammalia & & & 99 \\
\hline
\end{tabular}

water level in the nearby river. It may be seen from the diagram that on such a small area as the BNP chenges in numbers occurred in paralled in all biotopes except Tilio-Carpinetum typicum $(V)$. Factors thus existed which, by acting synchronously throughout a small area, caused similar changes in the various biotopes.

Of Insectivora only $N$. fodiens. which prefers moist biotopes, did not exhibit a decrease in numbers in 1949. In Rodentia, on the other hand, only $M$. arvalis and $S$. betulina were trapped in lower numbers in 1948 (Table 14). $M$. arvalis is not a constant component of natural forest communities and probably the large numbers of the other rodents in 1948 
exerted some sort of ecological pressure on it. S. betulina differs so greatly with respect to its biology from the other rodents ( $\mathrm{K} u \mathrm{bik}, 1952$ ) that comparison of quantitative variations is difficult. The quantitative relations before the peak period and after this period are characteristic when compared with numbers during the peak period (Table 14). With Insectivora the quantitative state after the peak period is higher than before it. The decrease in numbers is therefore slight. With rodents the opposite is the case. After the peak, numbers are far smaller than before it, and the decrease is abrupt.

Table 15,

Number of Insectivora and Rodentia in 1947 and 1949 in relation to number in 1948 (taken as 1.00).

\begin{tabular}{|c|cc|cc|cc|}
\cline { 2 - 6 } Biotope & \multicolumn{2}{|c|}{ Insectivora } & \multicolumn{2}{|c|}{ Rodentia } & \multicolumn{2}{c|}{ Micromammalia } \\
& 1947 & 1949 & \multicolumn{2}{c|}{1947} & 1949 & \multicolumn{2}{c|}{1947} & 1949 \\
\hline IX & - & 2.55 & - & 1.34 & - & 2.04 \\
VIII & - & .97 & - & 1.21 & - & 1.03 \\
VII & .26 & .44 & .64 & .60 & .37 & .49 \\
IV & .26 & .17 & .28 & .18 & .27 & .17 \\
I & .42 & .79 & .29 & .18 & .36 & .53 \\
II & .60 & .73 & .56 & .20 & .59 & .59 \\
III & .52 & .70 & .83 & .18 & .59 & .59 \\
IIIa & .35 & .46 & .46 & .26 & .38 & .63 \\
VI & .53 & .71 & .42 & .24 & .48 & .49 \\
V & .81 & 3.05 & .42 & .92 & .68 & 1.72 \\
\hline
\end{tabular}

The same regularity occurs in Insectivora and Rodentia in each of the biotopes (Table 15).

\subsection{Effect of Abiotic and Biotic Factors on Qualitative Variations} in the Communities

An attempt has been made to correlate variations in certain habitat factors with variations in the numbers of small mammals from the long-term viewpoint (Table 17, Fig. 12). Particular attention was paid to variations in precipitation, winter air temperature and thickness of the snow cover. In can be seen (Figs. 18-19,21) that it is impossible to extract any simple relation, between variation in amount of precipitation over a period of several years and the quantitative dynamics of small mammals.

The winter period was characterized by air temperature and snow conditions. If comparison is made of the winter conditions with variations 


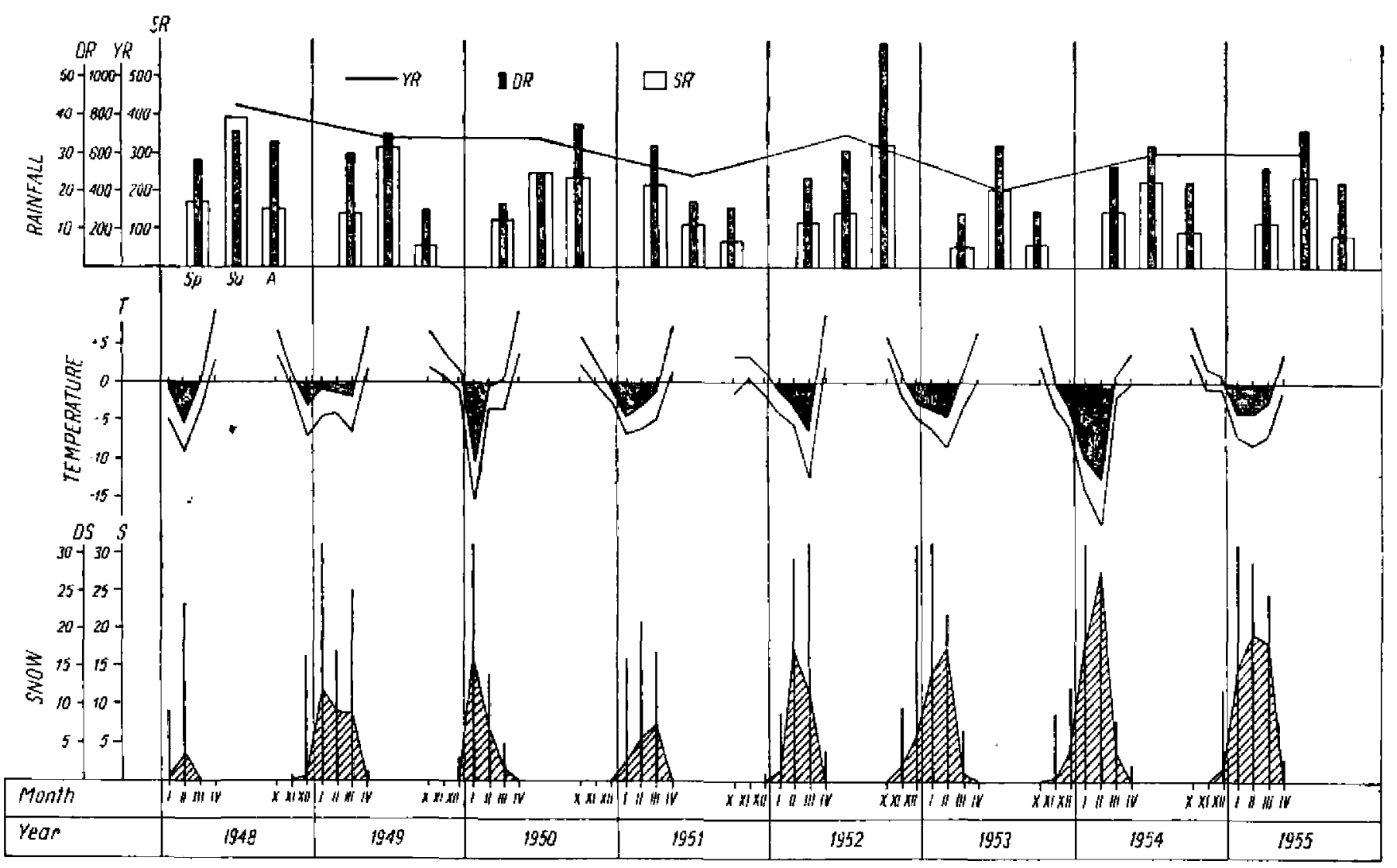

Fig. 22. Variations in some meteorological parameters for period 1948-1955.

- Annual precipitation (YR), seasonal precipitation $(S R)$ in spring ( $S p)$, summer ( $(S u)$ and autumn $(A)$ in mm and number - Temperature $(T)$ monthly average and average minimum temperature for period October-April. - Thickness of snow
cover $(S)$ and number of days with snow cover (DS) for period October-April. 
in numbers of Micromammalia it is possible to find a closer connection than when precipitation is analysed. Long winters (1948/1949, 1950/51, $1952 / 53,1953 / 54$ ) are unfavourable to survival of Micromammalia to subsequent years. Winters in which the snow cover is not very thick but temperatures are fairly low (1950/51) are more unfavourable to the populations than years in which low winter temperature are accompanied by thick snow cover $(1952 / 53)$. It is thus clear that the insulating role of the snow cover, under the conditions prevailing in the $B N P$, contributes considerably to improving conditions for small mammals to survive the winter (Fig. 22).

It would seen that the winters in which low temperatures occurred fairly late in the season $(1951 / 52,1954 / 55)$ do not cause reduction of numbers in the early part of winter. They probably allow a longer time

Table 16.

Dynamics of heavy seed fall *) from $1947-1949$ in forest biotopes in $\mathrm{mg} / \mathrm{m}^{2}$ (after unpublished data of Forestry Research Institute at Bialowieża).

\begin{tabular}{|c|c|c|c|}
\hline Biotope & 1947 & 1948 & 1949 \\
\hline I & - & - & - \\
II & - & - & - \\
III & - & - & 7,300 \\
IIIa & 74,350 & - & 430,380 \\
IV & - & - & - \\
V & 85,620 & 12,090 & 72,430 \\
VI & 27,690 & 650 & 647,660 \\
VII & 3,660 & 3,170 & 6,660 \\
\hline
\end{tabular}

*) Quercus, Carpinus, Tilia, Acer, Fraxinus, Corylius.

for accumulating stores for the winter period and contribute to maintaining a better condition in those individuals which enter the overwintering period. The summers of 1952 and 1955 were preceded by this type of winter and they show considerable increase in the numbers of Micromammalia compared with previous years.

The food supply in the habitat in different years exerts an important influence on the numbers of small mammals, particulary Rodentia. Summers with high production of tree and shrub seeds seem to influence the quantitative dynamies of $A$. flavicollis and $C$. glareolus. 1947 was characterized by high seed production (Table 18). The subsequent year, 1948 , was a peak year for rodents in all biotopes, but was also a poor year for plant species producing heavy seeds. This was probably the reason why numbers of rodents decreased in 1949. The fairly long winter of $1948 / 49$ created worse conditions for the survival of rodents, with minimum stores of high-calorie seed foods. There was a good seed crop 
again in 1949, which contributed to the increase in the numbers of rodents in the biotopes examined in $1950(I, I I, V I)$. The cold weather in the winter of $1949 / 50$ began fairly late, which enabled the animals to accumulate larger stores of seeds for the winter and to enter the overwintering period in good condition. In 1948, despite the generally poor seed crop, the foods available in Tilio-Carpinetum (V) were far greater than in other biotopes (Table 16). The may be the reason why the numbers of rodents in this biotope in 1949 were only slightly reduced, by comparison with general depression in numbers in the other biotopes. Absolute values of seed fall are available only for $1947-1949$. The values for the

\section{Table 17.}

Influence of numbers of dominants ( $S$. araneus, C. glareolus) on numbers of other species of small mammals (trappings in Peucedano-Pinetum, 1947-1955).

\begin{tabular}{|c|c|c|c|c|c|c|c|c|c|}
\hline Species & 1947 & 1948 & 1949 & 1950 & 1951 & 1952 & 1953 & 1954 & 1955 \\
\hline $\begin{array}{l}\text { S. araneus } \\
\text { Other Insectivora } \\
\text { Dominant in } \% / 1\end{array}$ & $\begin{array}{l}190 \\
47 \\
80.2\end{array}$ & $\begin{array}{c}337 \\
56 \\
85.8\end{array}$ & $\begin{array}{c}247 \\
39 \\
86.4\end{array}$ & $\begin{array}{l}133 \\
82 \\
61.9\end{array}$ & $\begin{array}{l}94 \\
76 \\
55.3\end{array}$ & $\begin{array}{c}195 \\
118 \\
62.3\end{array}$ & $\begin{array}{c}212 \\
62 \\
77.4\end{array}$ & $\begin{array}{l}272 \\
37 \\
88.0\end{array}$ & $\begin{array}{c}346 \\
54 \\
86.5\end{array}$ \\
\hline $\begin{array}{l}\text { C. glareolus } \\
\text { Other Rodentia } \\
\text { Dominant in } 0 / 0\end{array}$ & $\begin{array}{l}39 \\
36 \\
52.0\end{array}$ & $\begin{array}{l}81 \\
52 \\
60.9\end{array}$ & $\begin{array}{l}11 \\
15 \\
42.3\end{array}$ & $\begin{array}{l}70 \\
69 \\
50.4\end{array}$ & $\begin{array}{l}64 \\
15 \\
81.0\end{array}$ & $\begin{array}{c}117 \\
24 \\
83.0\end{array}$ & $\begin{array}{l}121 \\
37 \\
76.6\end{array}$ & $\begin{array}{l}12 \\
21 \\
36.4\end{array}$ & $\begin{array}{l}260 \\
38 \\
87.2\end{array}$ \\
\hline
\end{tabular}

Table 18.

Percentage occurence of ecological groups of Micromammalia in groups of biotopes distinguished.

\begin{tabular}{|l|c|c|c|}
\hline \multirow{2}{*}{ Biotopes } & Hygrophilous & \multicolumn{2}{|c|}{ Feedirg chiefly on } \\
\hline & & invertebrates & seeds \\
IX & 67.4 & 69.8 & 14.7 \\
VIII, VII, IV & 9.7 & 78.5 & 13.3 \\
I, II, III, IIIa & 3.2 & 76.5 & 16.5 \\
VI, V & 2.8 & 59.8 & 23.5 \\
\hline
\end{tabular}

following years are estimates only and apply to the percentage of fruiting of certain species of trees in the tree stands of the $B N P$ (jointly). According to the data oak fruited abundantly in 1952 and 1954, that is, years preceding increase in the numbers of Rodentia. The influence of the food supply is thus clear.

The period $1950-1951$ is fairly characteristic. In 1950 there was increase in numbers in Peucedano-Pinetum (II) of both C. glareolus and other representatives of Rodentia (chiefly Microtidae). The winter 1950/51 did little to reduce the numbers of $C$. glareolus (from 70 do 64 individuals), while the remaining rodents exhibited a marked decrease in num- 
bers in 1951. This was certainly due to the food availability and the winter period of $1950 / 51$. This winter was very long with a relatively low temperatures, and a fairly thin snow cover. The red-backed vole population, survived this period better than the other Microtidae which feed on lower-calorie food and do not collect winter stores. The low air temperature led to marked reduction in soil temperature and thus caused intensive reduction of the overwintering microtines.

Examination was made of the influence of dominants on the numbers of the other species (Table 17). In the Peucedano-Pinetum (II) association the dominants are $S$. araneus and $C$. glareolus. With Rodentia variation in the dominants' abundance is accompanied by parallel variations in the numbers of the other rodents. These variations take place at different rates, hence the percentage of the dominant in the community differs in different years. With Insectivora the picture is similar in the majority of cases, in only three of which are there differences in the direction taken by variations in numers of dominants and other species. It would appear that interspecific competition does not affect the variations in numbers of different species in the community. The existence of variations in habitat conditions for species occupying similar ecological niches leads in principle to parallel variations in their numbers. Competition may, however, contribute to establishment of a certain average level of density of different species in a given small mammal community.

It is clear from the above discussion that abiotic and biotic factors, by variations in their parameters over a long period of time, cause fluctuations in different species and consequently variations in the reciprocal relations between the various components of communities leading to changes in time in the physionomy and structure of the small mammal communities.

\section{DISCUSSION}

The method of quantitative analyses of Micromammalia used in this study has met with considerable criticism, chiefly from Borowski \& Deh n el (1952). Many such objections, frequently unsupported by evidence of their validity, have Iead to limitation in the application of this method in ecological studies.

The first objection is concerned with the degree to which one area can be representative of a whole biotope. The trapping areas were set up by J. J. Karpins $\mathrm{ki}$ in the centre of large stretches of vegetation typical of the given biotopes. Captures from control areas could not disprove that they were representative of the biotope, as the areas were situated near other biotopes (Borowski \& Dehnel, 1952) and thus caught 
animals in principle not from typical stretches of the biotope (on account of the activity of Micromammalia). It would appear that with a constant turnover of Micromammalia (Andrzejewski \& Wierzbowska, 1961; Andrzejewski, 1963; Trojan \& Wojciechowska, $1964 \mathrm{a}$ ) processes taking place in the trapping area of 0.25 ha are related to what takes place in neighbouring areas, and not only in the area in which the traps have been set. It may therefore be considered that such areas are representative of the biotope.

The second objection is concerned with selective trapping of certain species and even of categories of individuals of the same species. More recent studies supply proof of this (Buchalczyk \& Pucek, 1968; Pucek, Ryszkowski \& Zejda, 1970). Nevertheles, with comparative studies made in all biotopes by a uniform method and over a fairly long period, quantitative and qualitative differences between communities from different biotopes are surely real. Data on quantitative relations between species are undoubtedly not fully comparable. For instance the easy capture of Insectivora in pitfalls has been clearly demonstrated (Kuceruk et al., 1965; A u lak, 1967; Chełkowska, 1967). To get round this problem dominance in a community was evaluated separately for Insectivora and Rodentia. In addition dominance indices in Rodentia have been admitted to be relative when compared between biotopes. Within the biotope the role of the species in a community has been defined, without recognizing the quantitative proportions of species as real.

The trapping method used gives the dynamic density of Micromammalia, as does the method of trap-lines, which has been criticized by, inter alia, $\mathrm{K}$ u $\mathrm{c}$ e $\mathrm{r} \mathrm{u}$ et al., 1963. The method used here would appear to be even better than trap-lines. If it is assumed that there are certain permanent paths along which Micromammalia move about (O lszewski, 1963; Trojan \& Wojciechowska, 1964b; Andrzejewski et al., 1966) then an area of 0.25 ha can embrace both areas through which 'these paths run and also areas less thoroughly penetrated by small mammals. With the known clumped distributions of Micromammalia (Andrzejewski \& Glogowska, 1962; Opuszyński \& Trojan, 1963; Trojan \& Wojciechowska, 1964b) the area method of sampling guarantees that both densely and thinly settled areas are included. The use of pitfalls as traps repeatedly catching these animals, eliminates the influence which the number of traps on a trapping site has been found to have on the number of captures (A $\mathrm{ndrze}$ jewski et al., 1966). This method also permits the dynamics of Micromammalia to be followed during the yearly cycle. Taking into consideration all these points, it would seem that material collected from perma- 
nent trapping areas provides sufficient bases for correct definition of the preferences of small mammals, for definition of their relative dominance, for comparison between biotopes and for defining the composition of communities. Long-term trapping also permits the relative variations in numbers over a period of several years to be followed.

Sor ensen's formula (M a c F a d y e $n, 1963$ ) in general use in phytosociology, was used for comparing similarity of communities. It became necessary here take into consideration quantitative relations, as basing findings only on the occurrence or non-occurrence of a species was impossible in Micromammalia communities, since the majority of the 14 species of small mammals analysed occur in all the study biotopes. Similarity of dominance ( $\mathrm{Ba} \log \mathrm{h}, 1958$ ) was mainly used. The index calculated in this way defines the similarity of communities with respect to the percentage of the various species in the community and thus also the similarity of percentage of ecological niches in the biotope. This index converts the numbers of Micromammalia in all biotopes to a common value $(100 \%)$. The diagram of similarity shown in Fig. $12 \mathrm{~b}$ took into consideration absolute quantitative relations and confirmed the correctness of the arrangement of biotopes in a group according to similarity of dominance of community. The groups of biotopes distinguished according to similar communities of Micromammalia also possess similar annual spectra of the percentage of Insectivora and Rodentia. In trapping using pitfalls the preponderence of Insectivora over Rodentia found in all biotopes is not of course a reliable value, in view of the decided preference for these traps exhibited by Insectivora (A u la k, 1967; $\mathrm{Pu}$ c e k, 1969).

Considerable differences were found in the physionomy and structure of communities in different years. This results from the different abundances of the various species. Variations in the population density of a given species depend both on biotic and abiotic factors and on intrapopulation relations. Optimum factors cause an increase in density by increasing the number of litters and number of young per litter ( $\mathrm{B}$ rowski \& Dehnel, 1952; Koshkina, 1967; Kormilicina, 1966). In turn excessive reproduction reduces the reproductivity of a population (Petrusewicz, 1963; $\mathrm{T}$ a $\mathrm{nak} a, 1964)$. High density leads to intrapopulation fighting and fights between species, which increase migrational tendencies (Boret, 1963; Andrzejewski, Dominas \& T a r w id, 1964; A l i e v, 1965). During a period of high density migrants occupy even biotopes unfavourable to them, whereas during a period of low numbers Micromammalia are found mainly in their native biotopes (Wasilewski, 1960; Andrzejewski, Kajak \& Pieczyńska, 1963). 
All factors encouraging abundance of Micromammalia in different biotopes cause the variations in the similarity coefficients of communities found in the present study (Table 10, Fig. 16). The parallel nature of Micromammalia dynamics in almost all terrestrial biotopes may point to the fact that changing factors of the microhabitat influence the habitat factors of the different biotopes in the same direction.

Part of the activity of epigeic Micromammalia takes place below ground (in the superficial layers of the soil) and in the layer above ground level up to the height of less than $1 \mathrm{~m}$. The water relations in the soil may directly cause a reduction in the numbers of small mammals by flooding burrows, but it would seem that this factor is not of decisive importance in view of the possibility of migration to higher ground ( $T$ a $s t, 1966$ ). Nor is there any correlation between seasonal distribution of precipitation and the number of days with precipitation, and the variations in the numbers of Micromammalia.

The influence of the winter period on the abundance of Micromammalia has emphasised in this study. Borow ski \& Dehnel (1952) stated that this influence in negligible, but their underestimation was due to the lack of empirical data defining relations in and above the soil in winter. It seems indeed that the winter period is critical for Micromammalia and causes considerable losses in their populations ( $\mathrm{S} n \mathrm{ig}$ irevskaja, 1955; Ehrlich, 1957; Gli wicz et al., 1968; Górecki, 1968; Pe$\mathrm{trusewicz}$ et al., 1968). The presence or absence of snow cover also affects the degree of predation on Micromammalia ( $\mathrm{G}$ u s iev, 1952).

The effect of the winter period is more distinct when we also take into consideration food conditions in autumn, particularly seed fall. The influence of the amount of seed fall is not of course evident in the fluctuations of Insectivora. The greater part of their food consists of invertebrates, of which there is probably always a sufficient supply (D e h n el, 1949; M ezhzherin, 1958; $\mathrm{K}$ is i elewska, 1963). The effect of the seed yield on the abundance of rodents the following year was, however, very marked. Although rodents change to feeding on food consisting of green parts when no seeds are available ( $\mathrm{S} \mathrm{n}$ i g i r e v s k a j a, 1955; K o rmilicina, 1966), in the case of species such as A. flavicollis or C. glareolus the lack of high-calorie food during the winter may make it more difficult for the overwintering population to survive. The lack of food in winter also causes reduced reproductive output in those individuals which survived the winter, or even postponement of the reproduction period (Snigirevskaja, 1955; Golikova, 1959; A damczewsk a, 1961; K u bik, 1965).

Intrapopulation relations undoubtedly exert a considerable influence on the dynamics of Micromammalia (Christian, 1963; Petruse- 
w i c $z, 1966$ ). In the present study increased numbers of dominants were not found to lead to reduction of the other elements of the community (Table 17), despite the fact that Pivovarova (1955) and Andrzejewski \& Wrockawek (1961) found that some components of the community are ousted by dominants. The observations of these authors would appear to be the result of trapping data callected for too short a period of time. Variations in the numbers of dominants and the other elements of the community may then take place in different directions,

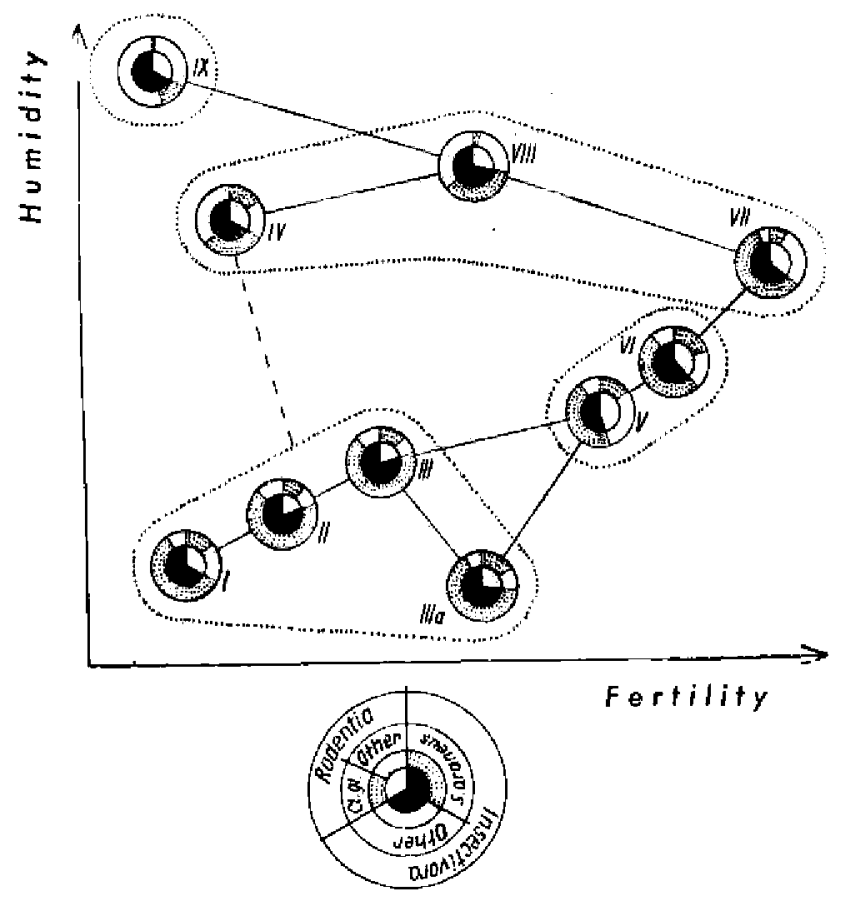

Fig. 23. Micromammalia communities in relation to humidity-fertility grid for 10 biotopes and possible directions of succession.

not always giving evidence of the pressure of dominants on species already decreasing in numbers.

The correlation found between some habitat factors and quantitative dynamics of Micromammalia does not permit the identification of any of these factors as exerting a decisive effect on fluctuations in numbers. Their complex action on the numbers of small mammals in different years results in differentiation in physionomy and structure of the communities from the long-term viewpoint.

The long-term variations in communities defined in this discussion are the result of oscillation round a certain average value. Shortlived varia- 
tions in habitat factors cause slight variations in Micromammalia communities, without visible changes in plant associations. If changes in habitat factors are characterized by a certain direction this may lead to succession of both plant and animal associations. In the biotopes of the Białowieża National Park succession of plant associations is imperceptible over short periods of time. It may be evoked by a change in the basic habitat parameters leading to a change in the habitat. Succession of animal communities also takes place together with this, through the change in plant associations. Attempts may therefore be made to define the presumed directions which changes in epigeic communities of Micromammalia will take depending on the directions of changes in habitat factors. For this purpose the Micromammalia communities have been set out on a fertility-humidity grid (Fig. 23). These two habitat factors to a great extent determine the existence of given biotopes. Biotopes were grouped according to structure of small mammal communities and the possible directions of succession indicated. Probable changes in time were equated with changes in space. Let us consider the basis directions of succession.

I - change in habitat from biotopes Peucedano-Pinetum and Pino-Quercetum to Tilio-Carpinetum cause increase in the dominance of Rodentia. Increased food production, particulary of seeds, results in a higher percentage of seed-eaters and a relatively smaller percentage of species feeding chiefly on invertebrates (Table 18). On account of the lack of significant differences in humidity, the percentage of hygrophilous forms does not exhibit any significant change.

II - change in biotopes Peucedano-Pinetum and Pino-Quercetum in the direction of moist and trophically poor Pinetum turfosum causes increase in the percentage of hygrophilous forms.

III - change in biotopes Tilio-Carpinetum in the direction of moist assaciations (VII, IX) causes considerable increase in hygrophilous forms and simultaneously considerable reduction in the percentage of seed-eaters.

IV - a change in the riverside biotope (VIII) in the direction of an aquatic biotopes $(I X)$ causes significant changes in the composition of the Micromammalia community. More than half the individuals are hygrophilous forms. Seed-eaters feed chiefly on grass-seeds. The majority of the elements of the community are forms feeding chiefly on insects and other invertebrates.

The possible directions of succession in communities may result in two ways. The quantitative changes of some habitat factor, in the direction of the value characteristic of a biotope adjacent in the succession order, causes certain shortlived changes in the community from the adjacent 
biotope. Long-lasting directed changes cause this state to become permanent and also cause a permanent change in the structure of the Micromammalia community together with the change in habitat.

Acknowledgments: My grateful thanks are due to Dr. hab. Z. Pucek, Head of the Mammals Research Institute, Polish Academy of Sciences, Bialowieża, for his unfailing assistance, guidance and hospitality at the Mammals Research Institute, as they are to Dr. W. Sokolowskt and Dr. ing. J. Wolak of the Forestry Research Institute for putting at my disposal both phytosociological descriptions and all other material held in the Institute referring to the study areas.

I must also record my gratitude to $\mathrm{Dr}$. J. L. O ls $\mathrm{z}$ e w sk i for making meteorological data available and Dr. S, B or o w s $\mathrm{ki}$ for data on the seed yield of forest trees and shrubs in the BNP, and Dr. P. E v a n s, Department of Zoology, University of Durham for making valuable corrections to the text.

My thanks are also due to the staff of the Mammals Research Institute, P.A.S. at Bialowieza, who through their work and assistance and their friendly attitude towards me facilitated the execution of this study.

\section{REFERENCES}

1. A A a mczewska A. K., 1959: Untersuchungen über die Variabilität der Gelbhalsmaus, Apodemus flavicollis flavicollis (M elchior, 1834). Acta theriol., 3, 10: 141-190.

2. Adam czewska A. K., 1961: Intensity of reproduction of the Apodemus flavicollis (M elchior, 1834) during the period 1954-1959. Acta theriol., 5, I: $1-21$.

3. Aliev F. F., 1965: Dane o migracjach ssaków. Ekol. pol. B, 11, 3: 233-239.

4. Andrzeje wski R., 1963: Processes of incoming, settlement and dissapearance of individuals and variation in the numbers of small rodents. Acta theriol., 7, 11: $169-213$.

5. Andrzejewski R., Bujalska G., Ryszkowski L. \& Ustyniuk $J_{\text {, }}$ 1966: On a relation between the number of traps in a point of catch and trapability of small rodents. Acta theriol., 11, 13: $343-349$.

6. Andrzejewski R., Dominas H. \& Tarwid K., 1964: Konkurencja miedzygatunkowa a całosciowość populacji. Ekol. pol. B, 10, 3: 173-181.

7. Andrzejewski R. \& G log owska J., 1962: The influence of the layaut of traps and lenght of time for which they remain set on the distribution of capture of small rodents. Ekol. pol. A, 10: 285-293.

8. Andrzejewski R., Kajak A. \& Pieczyńska E., 1963: Efekty migracji. Ekol. pol. B, 9, 2: 161-172.

9. Andrzejewski R. \& Wierzbowska T, 1961: An attempt at assessing duration of residence of small rodents in a defined forest area and the rate of interchange between individuals. Acta theriol, 5, 12: 153-172.

10. Andrzejewski R, \& Wroclawek H., 1961: Mass occurence of Apodemus agrarius (Pallas, 1771) and variations in the number of associated $M u$ ridae. Acta theriol., 5, 13: 173-184.

11. A ulak W., 1967: Estimation of small mammal density in three forest biotopes. Ekol. pol. A, 15, 39: 755-778.

12. Balog h J, 1958: Lebensgemeinschaften der Landtiere: 1-560. Berlin-Budapest.

13. B or et J., 1963: Observations sur la sedentarite et le domaine vital du mulot sylvestre (Apademus sylvaticus) en Camarge. Terre et la Vie, 3: 266-279. 
14. Borowski S, \& Dehnel A., 1952: Materialy do biologii Soricidae. Annls Univ, M. Curie-Sklodowska, C, 7: 305-448.

15. Buchalczyk T. \& Pucek Z., 1968: Estimation of the numbers of Microtus oeconomus using the Standard-Minimum method. Acta theriol,, 13, 29: 461-482.

16. Chelkowska H., 1967: An attempt at comparing two methods of trapping small rodents (in pitfalls and live tiaps), Ekol. pol. A, 15, 40: 779-785.

17. Christian J. J., 1963: Endocrine adaptive mechanismus and the physiologic regulation of population growth. [In "Physiological Mammalogy*, Eds, W. V. Mayer \& R. G. van Gelder]. 1: 189-354. Academic Press, New York.

18. Chu d oba S. \& H u miński S,, 1961: Podwrocławskie tereny nawożone miejskimi ściekami jako biotop owadożernych i gryzoni. Przegl. zool., 5, 2: 132-137.

19. Chudoba S. \& Humiński S., 1963: Owadożerne i gryzonie w osiedlu ludzkim podczas jesieni i zimy. Zesz. Nauk. WSR Wrocław, Zootechn., 11: 11-25.

20. Chudoba S., Humiński S. \& Wójcik I., 1961: Drobne ssaki Wroclawia. Przegl. zool., 5, 4: 362-374.

21. Dehnel A., 1946: Przyczynek do znajomosci przedstawicieli rodzaju Microtus S chrank z Polesia i Wileńszczyzny. Fragm. Faun., 5: 1-24.

22. Dehnel A., 1949: Badanja nad rodzajem Sorex L, Annls M. Curie-Sklodowska C, 4: 17-102.

23. Dehnel A., 1950: Badania nad rodzajem Neomys Ka u p. Annls M. Curie-Sklodowska $C, 5: 1-63$.

24. Ehrlich S., 1957: Stosunek nie zapadających $w$ sen zimowy Simplicidentata do warunków zimowych. Ekol. pol. B, 3, 1: 17--35.

25. Gliwicz J., Andrzejewski R., Bujalska G. \& Petrusewicz K., 1968: Productivity investigation of an island population of Clethrionomys glareolus (S c h r e be $\mathrm{r}, 1780$ ). I Dynamics of cohorts. Acta theriol., 13, 23: 401-413.

26. Golikova V. E., 1959: Sezonnyje osobennosti poselenija lesnyh myšej i rižih polevok $\mathrm{v}$ Voroneżskom Zapovednike [In "Geografija naselenija nazemnyh żiwotnyh i metodyka jego izučenija a], 7: 308-310, Moskva AN SSSR.

27. Gorecki A., 1968: Metabolic rate and energy budget in the bank vole. Acta theriol., 13, 20: $341-365$.

28. Grodziński W., 1959: Sukcesja zespolów drobnych ssaków na zarastającym zrębie i zsuwie gorskim w Beskidzie Średnim (Karpaty Zachodnie), Ekol. pol. A, $7:$ :3-143.

29. Gus iev V. M., 1952: O značeni glubiny snez̆nogo pokrova dlja ptic pitajuščihsia myševidnymi gryzunami. Zool. Zh., 31: 471--473.

30. Haitlinger R., 1965: Morphological analysis of the Wroclaw population of Clethrionomys glareolus (S c hreber, 1780). Acta theriol., 10, 18: 243-372.

31. Haitlinger R, \& Korzeniowski A, 1962: Badania ekologiczne drobnych ssakow na wybranym terenie w okolicy Wroclawia. Acta Univ. Wrat., Zool., 1: $35-54$.

32. Karpiński J. J., 1949: Materialy do bioekologii Puszczy Bialowieskiej. Inst. Bad. Leśn., A, 56: 1-212, Warszawa.

33. Karpiński J. J., 1954: Ptactwo w biocenozie Bialowieskiego Parku Narodowego (badania). Roczn. Nauk Leśn., 5: 3-104.

34. Kis i lew k a K., 1963: Food composition and reproduction of Sorex araneus Linnaeus, 1758 in the light of parasitological research. Acta theriol., 7, 9: $127-153$. 
35. Kormilicina V. V., 1966: K sezonnoj dinamike čislennosti myševidnyh gryzunov v zapovednike Bukovyh Lesov. Izuč. i Ochr. Prir.: 747-753, Mińsk.

36. Koshkina T. V, 1967: Ekologiceskaja diferencjacija vida na primere krasnoj polevki taigi Salairskogo Krjaža. Acta theriol., 12, 11: 135-163.

37. Kosiba A., 1951: Zagadnienje pionowych różnic klimatycznych $w$ przyziemnych warstwach atmosfery. Prz. Geogr., 3-4: 98--110.

38. K o w a ls k i $K$, 1950: Badania nad ekologia drobnych ssaków leśnych $w$ okolicy Krakowa. PAU Mat, do Fizjogr. Kraju, 22: 1-20.

39. Kratochvil J. \& Gaisle $\mathrm{z}$ J, 1967. Die Sukzession der kleinen Erdsäugetiere in einen Bergwald Sorbeto-Piceetum. Zool. listy, 16:301-324.

40. Kubik J., 1952: Badania nad morfologia i biologia smuziki (Sicista betulina Pa11.) z Bialowieskiego Parku Narodowego. Annls Univ. M. Curie-Sklodowska, C, 7: 1-63.

41. Kubik J, 1965: Biomorfological variability of the population of Clethrionomys glareolus (S chreber, 1780). Acta theriol., 10, 10: 117-179.

42. Kučruk V. V., Tupikova N. V., Evsejeva V. S. \& Zaklinskaja V. A., 1963: Opyt kritičeskogo analiza metodyki kolicestvennogo učeta gryzunov i nasekomojadnyh pri pomošči lovuškolinij [In „Organizacija i metody uêta ptic i vredn. gryz.«]: 218-227, Moskva.

43. M a c fadyen A., 1963: Animal ecology. Aims and methods. Academic Press: $1-344$, London.

44. M a tuszkiewicz W., 1952: Zespoly leśne Białowieskiego Parku Narodowego. Annls Univ. M. Curie-Sklodowska, C suppl., 6: 1-218.

45. M ezhzherin V. A., 1958: K voprosu o pitanil obyknoverınoj i maloj burozubok (Sorex araneus L. i S. minutus L.), Zool. Zh., 37: 948-953.

46. Obmiński Z., 1960: Badania nad wahaniami poziomu wód gruntowych $w$ niektórych biotopach Bialowieskiego Parku Narodowego. Prace IBL, 201: 1162.

47. Olszewski J., 1963: Wechsel der Bewegung der Nager in Walde. Acta theriol., 7, 19: 372-373.

48. Opuszynski K. \& Trojan P., 1963: Distribution of burrows and elements of the population structure of small forest rodents. Ekol. pol. A, 11: 339-352.

49. Petrusewicz K., 1963: Population growth induced by disurbance in the ecological structure of the population. Ekol. pol. A, 11: 87-125.

50. Petrusewicz K., 1966: Dynamics, organization and ecological structure of population. Ekol. pol. A, 14, 25:413-436.

51. Petrusewicz K., Andrzejewski R., Bujalska G. \& Gliwicz J., 1968: Productivity investigation of an island population of Clethrionomys glareolus (S c hreber, 1780). IV. Production. Acta theriol., 13, 26: 435-445.

52. Pivovarova B. P., 1955: O razmešcenii i cislennosti gryzunov v zapovednike Belovežskaja Pušča. Uc. Zap. Mosk. Gos. Pę. Inst., 38, 3; 147-156.

53. Pucek $Z$, 1969: Trap response and estimation of numbers of shrews in removal catches. Acta theriol., 14, 28: 403-426.

54. Pucek Z., Ryszkowski L. \& Z ejda J., 1970: Estimation of average length of life in bank vole, Clethrionomys glareolus (Schreber, 1780). [In mEnergy flow through small mammal populations $\ltimes$, Eds. Petrusewicz K. \& Ryszk ow s k i L.], PWN - Polish Sci. Publ.: 187-201, Warszawa,

55. Skuratow i cz W., 1948: Badania nad fauna ssakow Zamojszczyzny. Fragm. Faun., 5: 233-292. 
56. Snigirevskaja E. M., 1955: Dannye po pitaniju i kolebaniju čislennosti želtogorloj myši w Zigulah. Zool. Zh., 34, 2: 432-440.

57. St i eve D., 1955: Small mammals communities of the North Seandinavian birch forest. J. Anim, Ecol., 24: 403-411.

58. Szafer W, Kulczýnski S. \& Pawlowski B., 1953: Rośliny polskie. PWN - Polish Sci. Publ.: 1-1020, Warszawa.

59. Tanaka R., 1964: Population dynamics of the Smith's Red Backed Vole in the highlands of Shikoku. Res. Popul. Ecol., 6: 54-66.

60. Tast J., 1966: The root Vole, Microtus oeconomus (Pallas) as an inhabitant of seasonaly flooded land. Acta Zool. Fen., 3: 127-171.

61. Tom a nek J., 1953: Badania nad przebiegiem temperatury gruntu i parowania w różnych biotopach leśnych Bialowieskiego i Wielkopolskiego Parku Narodowego. Prace IBL, 91: 1-71.

62. Tom a nek J., 1955: Badania nad przebiegiem temperatur powietrza w biotopach leśnych Białowieskiego Parku Narodowego. Roczn. Nauk Leśnych, 8; 179 -214 .

63. Tra c z y k. T., 1968: Zasobnośé siedlisk a produkcja runa leśnego. Ekol. pol. B, 14, 4: $321-324$.

64. Trojan P. \& Wojciechowska B., 1964a: Studies on the residency of small forest rodents. Ełcol. pol. A, 12: 33-50.

65. Trojan P. \& Wojciechowska B., 1964b: The distribution of small rodents and its causes. Ekol. pol. A, 12: 368-378.

66. Wasilewski W., 1960: Angaben zur Biologie und Morphologie der Kurzohrmaus, Pitymys subterraneus (De Sély - L ong cham ps). Acta theriol., 4, 12: $185-247$.

67. Zejda J. \& Klima M, 1958: Die kleinsäugetiere des Naturschutzgebietes "Kubany-Urwald (Boubin)«. Zool. Listy, 7: 292-308.

Received, September 9, 1970.

Mammals Research Institute, Polish Academy of Sciences, Bialowieża, woj. Bialystok.

Department of Game Managemen Warsaw Agricultural University Warszawa, ul. Rakowiecka $26 / 30$. (Present address)

Wladysław AULAK

\section{ZESPOEY DROBNYCH SSAKOW W BIOTOPACH BIAEOWIESKIEGO PARKU NARODOWEGO}

\section{Streszczenie}

W Bialowieskim Parku Narodowym, na 10 stalych powierzchniach $(0,25$ ha) $w$ kaźdym biotopie, dokonano odlowu drobnych ssaków w cyklu wieloletnim. Jako pułapki stosowano metalowe cylindry (por. B orowski i Dehnel, 1952). Stwierdzono 14 gatunków nazjemnych Micromammalia.

Przyjęto, ze metoda ciaglego odlowu, jest przydatna do określenia struktury zespolów ssaków, ich podobieństwa, do określania wybiórczości biotopów przez poszczegolne gatunki oraz do sledzenia względnych fluktuacji ilościowych drobnych gryzoni.

Zanalizowano wybiórczośc biotopów oraz dominację poszczególnych gatunkow w zespołach drobnych ssak $\delta w, w$ poszczególnych biotopach. Stwierdzono, ze poza ga- 
tunkami eurybiontycznymi (S. aroneus, S. caecutiens, S. minutus, C. glareolus) wszystkie pozostale wykazują znaczne przywiązanie do poszczególnych biotopów lub do grup biotopów o podobnych warunkach srodowiskowych (Ryc, 9).

Wykazano zmienność wskaźników wybiórczości i dominacji w aspekcie wieloletnim oraz koniecznośt określania tych wskaźników wedlug badań wieloletnich (Tabele $6-8$ ).

Porównano względne zagęszczenie Micromammalia w analizowanych biotopach (Ryc. 11) stwierdzając zależnośc zagęszczenia od warunków srodowiskowych.

Zespoly drobnych ssaków z poszczególnych biotopów porównano między sobą (Ryc. 12). Stwierdzono duża zbieżnosć podobieństwa między biotopami oraz podzial na grupy srodowiskowe biotopów, wedlug podobieństwa zespołów roslinnych i zespolow Micromammalia. Wykazano zmiennośc podobieństwa zespołów drobnych ssaków w różnych latach (Ryc. 16). Największe odrębnosci struktury poszczególnych zespolów mają miejsce $w$ roku minimalnej liczebności Micromammalia. Po roku kulminacyjnego zagęszczenia redukcja populacji gryzoni jest bardziej radykalna, natomiast u owadożernych zalamanie się liczebności jest niewielkie.

Zmiany liczebności Micromammalia w różnych biotopach terrestrycznych oraz stępnym.

u różnych gatunków zachodzą jednokierunkowo. Wahania liczebności gryzoni następują częseiej niż u owadożernych. Stwierdzono, że niekorzystne warunki zimowania maja znaczny wplyw na liczebnośc populacji głównie gryzoni w roku na-

Określono potencjalne kierunki sukcesji zespołów drobnych ssaków w zależnosci ad zmian czynników środowiskowych (Ryc. 23). 